\title{
Ekaterina Sobkovyak* Religious History of the Gaṇ̦ī Beam: Testimonies of Texts, Images and Ritual Practices
}

\section{DOI 10.1515/asia-2015-1001}

Abstract: The gandī beam is a monastic tool which was already known to have been used in Buddhist monasteries in ancient India for the purpose of calling the monks to gather for a joint activity. With the spread of Buddhism the instrument was transmitted to the Tibetan and later Mongolian Buddhist cultures. It has been in use in the Tibetan and Mongolian Buddhist monastic traditions till the present day. One of the most prominent cases of the gandi beam application in modern Mongolia relates to the poșadha ritual. In this article I attempt to present the history of the gaṇ̂i beam within the framework of material culture studies. The analysis aims at the investigation of the mutual relations between the artefact and the societies that have made use of it as well as of the ways in which these relations could have changed. In order to accomplish this task I study the testimonies of the original Sanskrit and Tibetan texts, religious images and accounts of ritual practices.

Keywords: gaṇ̂̄ beam, Tibetan Buddhism, Mongolian Buddhism, Material culture studies, poșadha ritual

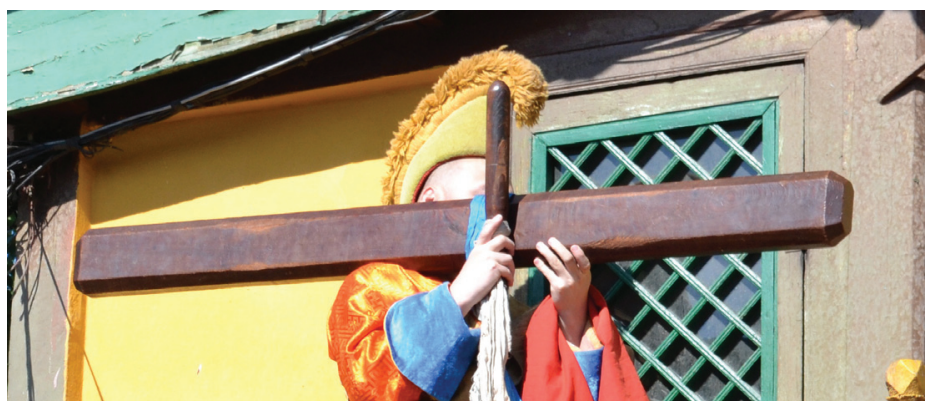

Figure 1: The gaṇ̣̂i beam and gaṇ̣̂̂-striker used in the Gandantegchenlin monastery, Ulan Bator, June 2011.

*Corresponding author: Ekaterina Sobkovyak, Universität Bern - Institut für Religionswissenschaft, Lerchenweg 36, 3012 Bern, Switzerland. E-mail: ekaterina.sobkovyak@relwi.unibe.ch 


\section{Introduction}

The inspiration for this article came from witnessing gandi beam striking in the Gandantegchenlin monastery of Ulan-Bator in summer 2011. The paper's conceptual focus was influenced by the international, cross-disciplinary, academic and associative lecture panel "Mongolian Space and Heritage", held in Paris in 2012 and organized by OTASIE's research group "Réflexions d'Asie”. The panel discussed tangible and intangible Mongolian heritage as well as the history of its formation and development within the frameworks of Mongolian culture. ${ }^{1}$

In the past few decades it has become common for scholars working in the classical humanistic disciplines to look at material objects more closely. This trend has been accompanied by the development of new methodologies and theories in material culture studies, which have called for the investigation "through artifacts of the beliefs - values, ideas, attitudes, and assumptions of a particular community or society at a given time". ${ }^{2}$ The gandī is an instrument known to scholars to have been made in the form of a wooden beam and to have been used in the Buddhist monasteries since ancient times for different purposes. Research into the history of the gandị beam involves data of different kinds, ranging from written texts, through to images and the beam itself, as a material object. It therefore provides a good opportunity to apply methods established within the field of material culture studies, combining them with theoretical and practical approaches traditionally used in philology, cultural anthropology and historical studies.

Although the starting point of my investigation is the gandi beam as a physical object, I will not limit the discussion to its intrinsic material features, i.e. to features which are observable and have been documented in texts and images. My purpose is to trace the history of this artefact and its development within the frameworks of Buddhist culture, placing special emphasis on changes in perception by the bearers of Buddhist tradition. Of even greater interest to me is the analysis of the factors that caused these changes and the affects that they had on the ways people used and expressed their attitude towards this object.

Material culture studies are generally based on the assumption that "objects made or modified by man reflect, consciously or unconsciously, directly or indirectly, the beliefs of individuals who made, commissioned, purchased, or used them, and by extension the beliefs of the larger society to which they belonged". ${ }^{3}$ The example of the gandi beam offers sufficiently abundant and

$1 \mathrm{http}: / /$ calenda.org/216883?file=1 (19.11.2014)

2 Prown 1982: 1.

3 Prown 1982: 1-2. 
relevant material for a case study of the mutual relations between an artefact and a society and the ways in which they can change.

In an attempt to better understand the transformations which material objects like the gandī may have undergone as part of Buddhist religious culture, I will make use of the common idea in the material culture studies that material objects "do "social work". "Social work" in this sense speaks to the capacity of objects to serve as signifiers of both social and subjective (of self) identity. ${ }^{4}$ Even more important is the comprehension of the material objects themselves as social objects into which they are transformed by being embedded in a narrative. ${ }^{5}$ Investigating the appearance of the gandi $\bar{\imath}$ beam as described in various sources, thus, goes hand in hand with the analysis of the narratives related to the object and the ways in which they have endowed it with social meaning. The investigation of the mechanisms of constructing such meaning and of its evolution might contribute to our understanding of the role that materiality plays in the creation and development of both practical and philosophical aspects of complex socio-cultural phenomena (such as religion).

\section{Semantics as a hint at the notion of form and material}

Mentions of the gaṇī can be found in various Buddhist treatises dating back to at least the first centuries CE. Many of these texts relate the events that took place during the life-time of the Buddha, thereby testifying to the application of the gandi by the communities of Buddhist monks during this period. This information, however, should certainly not be taken for granted. On the one hand, the texts were written several centuries after the occurrences they describe. On the other hand, the circumstances in which, according to the texts, the gandi $\bar{i}$ was used, allude to the existence of well-developed Buddhist monasteries which did not exist prior to the first centuries CE. ${ }^{6}$

While the question of the gandị application during the early days of the life of the historical Buddha should be set aside for further investigation, we may argue with a high degree of certainty that Indian Buddhist monasteries present at the beginning of our era made extensive use of the instrument. Schopen finds numerous textual testimonies in the Mūlasarvāstivāda-vinaya indicating that the

\footnotetext{
4 Woodward 2007: 134-135.

5 Harre 2002: 25.

6 Schopen 2004: 1-2.
} 
main reason for striking the beam was to call the monks to gather together for a joint activity. In these sources, the application of the gandi is usually described to have been associated not so much with a special spiritual event or sacral act, but rather with an everyday routine of monastic life or other mundane affairs. It was struck, for example, to announce a monk's death and to signal the beginning of the formal funeral proceedings, to call the monks to gather for a joint meal, or to alarm the residents of the monastery in case of danger, e.g., an attack by robbers. ${ }^{7}$ Schopen also notes indirect indications of the possibility of using the gandī as a physical weapon. ${ }^{8}$

The word gandi , with which the instrument came to be designated, is encountered in Indian languages such as classical Sanskrit and Pāli. Its etymology, however, seems to be problematic for scholars, as many modern dictionaries suggest interpretative definitions for the entry ganḍ̄ and explain it with the word "gong", which is a possible description of the instrument based almost exclusively on its sound-producing function. ${ }^{9}$

Discussing the etymology of the word gandị, Hu-von Hinüber stated that the word seemed not to have been documented in classical Sanskrit, while it was known to exist in the so-called Buddhist Sanskrit and Pāli. She referred among others to PTSD ${ }^{10}$ by Rhys Davids and Turner, who stated a possible connection between the Pāli gaṇ̣̂ and the Sanskrit ghanțā related to its second meaning, which is "a bell" according to the dictionary by Monier-Williams. ${ }^{11}$ One of the meanings that PTSD itself offers for gandī is "a gong". ${ }^{12}$ The same explanation can be found in BHSD, which is the only meaning proposed for the word gandi in this dictionary. ${ }^{13}$

7 Schopen 1992: 6; Schopen 2004: 261, 265, 269.

8 Schopen 2004: 267, 277, n. 11.

9 With the spread of Buddhism the term gandi i was transmitted directly, that is, phonetically to the Tibetan and consequently Mongolian languages. In the Tibetan sources and modern dictionaries it is presented in slightly divergent forms such as gaN $+D I$ or $g a N+D i$ and gaN DI or gaN+TI. Das 1902: 214; Tshig mdzod: 349; DGS: 301b; KrS: 346a; Grags pa rgyal mtshan: 2-5. Mongolian sources as well offer slightly different ways of writing the term down. All of the variants, however, keep close phonetic resemblance to the Indian original. Kas'yanenko 1993: 244, $\mathrm{N}^{\circ}$ 796; Ligeti 1942: 286, $\mathrm{N}^{\circ} 1058 ; 287, \mathrm{~N}^{\circ} 1050$. The Wylie and the extended Wylie transliteration schemes supported, among others, by the Thlib.org and Tbrc.org Internet resources are used in this article for the transliteration of Tibetan.

10 The meaning of this and other abbreviations can be found in the list of abbreviations at the end of the article.

11 Hu-von Hinüber 1991: 737-738; Monier-Williams 1974: 375; PTSD: 71.

12 PTSD: 71.

13 BHSD: 208. 
In an attempt to identify the appearance of the gaṇ̣̂i instrument etymologically, Hu-von Hinüber confronted our European understanding of the term "gong" as it is normally associated with a flat and round object made of metal, with a description of the gandī encountered in the Buddhist original sources, as well as in contemporary Tibetan-Tibetan-Chinese and Tibetan-English dictionaries. The fact is that the majority of the sources to which Hu-von Hinüber referred characterizes the gandī as a wooden instrument. Some even provide its measurements and define it as a beam. This led Hu-von Hinüber to the conclusion that the Pāli and Buddhist Sanskrit word gaṇ̣̂ is derived not from the classical Sanskrit gantha $\bar{a}$, but that it is semantically related to the middle Indian word ganthi, ${ }^{14}$ and therefore in Sanskrit, granthi. ${ }^{15}$

In my opinion, there is no contradiction between the numerous descriptions of the gandi found in the original Buddhist sources and presenting the instrument as a long, slim and smooth wooden beam, and the semantics of the word taken either in its Sanskrit or Pāli form. The fact is, when making her analysis, Hu-von Hinüber, for whatever reason, did not take into consideration the word gandi, as explained by the Monier-Williams dictionary. There it is "the trunk of a tree from the root to the beginning of the brunches". ${ }^{16}$ She also did not mention the first meaning suggested for the word gandi by PTSD, namely "a shaft or stalk, used as a bar". ${ }^{17}$

Later testimonies of texts and images that I will discuss in detail below provide a more definitive idea of the gandī as being a wooden beam. Regarded as the earliest available evidence of the existence of the object in question, the signifier gandī, taken in its different forms and with their semantics provide reason to believe that the instrument itself has not changed significantly in appearance since the days when it became included in the variety of material objects pertaining to Buddhist culture. Although the argument of semantics and

14 The second meaning proposed by PTSD for the word ganțhì is "a (wooden) block". Hu-von Hinüber herself noticed that the Sanskrit word granthi was provided without any similar explanation in either the Monier-Williams dictionary or the Böhtlingk/Roth dictionary. She also cited the dictionary by Mylius, in which the word granthi was furnished with the definition "Glocke". This definition, according to the scholar, was not found in the dictionaries by MonierWilliams or Böhtlingk/Roth. In fact, at least in the former the granthi is also defined as "a bell" just as in the dictionary by Mylius. This example, therefore, appears to be inadequate and breaks the scholar's own logic, bringing us back to the etymological connection between the classical Sanskrit ghanțāa and gaṇīi, which Hu-von Hinüer herself questioned. Hu-von Hinüber 1991: 739, 760, n. 22; Mylius 1992: 146; PTSD: 70; Monier-Williams 1974: 371; Böhtlingk/Roth 1858: 833.

15 Hu-von Hinüber 1991: 738-739.

16 Monier-Williams 1974: 344.

17 PTSD: 71. 
etymology should not be considered absolutely plausible, I suggest highlighting its importance in building the history of the gandị beam, as it agrees much with and supports textual data dating back to the first centuries of Buddhist cultural development.

\section{Classifications of the ganḍi beam and conceptual differences in their basic criteria}

One of the starting points in the examination of a physical object within the framework of material culture studies is to classify it among other artefacts. Starting with the notion that the "most promising mode of classification is by function" Prown suggested the following classification of material objects:

1. Art (paintings, drawings, prints, sculpture, photography)

2. Diversions (books, toys, games, meals, theatrical performances)

3. Adornment (jewelry, clothing, hairstyles, cosmetics, tattooing, other alterations of the body)

4. Modifications of the landscape (architecture, town planning, agriculture, mining)

5. Applied arts (furniture, furnishings, receptacles)

6. Devices (machines, vehicles, scientific instruments, musical instruments, implements). ${ }^{18}$

The functional affiliation of the ganḍ beam is not obvious. Judging from descriptions of its application provided by sources dating from different times the gandi $\bar{i}$ has been used for various purposes and, thus, could have been ascribed to different categories of the aforementioned classification, sometimes probably to several categories simultaneously.

Some original Buddhist sources which contain fragments devoted to the gaṇī present classifications of the instrument based on divergent criteria. Studying these classifications might be helpful in the investigation of the dynamics of the gandị sunctionality.

One of the earliest texts that include a classification of the gandi beam is the Poșadhavastu. This text comprises a part of the Vinayavastu ${ }^{19}$ treatise, which in

18 Prown 1982: 2-3.

19 This part of the Sanskrit Vinaya corresponds to the Khandhaka section of the Theravāda Vinaya written in Pāli. Hu-von Hinüber 1994: 52; Hirakawa 1990: 72. 
its turn is included in the Vinayapitaka, one of the three main parts of the Indian Buddhist canon, the Tripițaka. ${ }^{20}$

In the translation of Hu-von Hinüber the classification of the gandī from the Poșadhavastu reads as follows:

So gab es fünf Arten von Gạ̣ḍī; (die Gaṇ̣̂ī) für die gesamte Gemeinde (sārvasamghikā), die Gaṇḍ̄ für die Verhandlung (karmagaṇḍ̄), die Gaṇḍ̄ für den Todesfall (amsagaṇ̣̂̄), die Gaṇḍ̄ für die Meditation (prahānagaṇ̣̂̄i) und die Gaṇḍ̄ für den Unglücksfall (āpadgaṇdīi). ${ }^{21}$

The text continues with the description of the exact method for striking each type of the gandị listed in the passage given above. It does not, however, contain any details concerning the appearance or physical features of the instrument or any further clarification of the occasions on which the instrument was to be struck in the particular modes provided. I therefore consider it highly probable that the Poșadhavastu classification is based on the criterion of special occurrence. However, it is not quite clear whether the text refers to the same instrument that was struck in different ways on different occasions or rather to five instruments that varied from one another according to particular physical characteristics.

The text of the Poṣadhavastu belonging to the Mūlasarvāstivāda school was transmitted into Tibetan and later adapted for Mongolian Buddhist culture, and included in the Tibetan and Mongolian Kanjur. ${ }^{22}$ The Tibetan version of the text

20 It is probable that some version of the Poșadhavastu constituted a part of the Vinaya corpus of every school of Indian Buddhism. Currently, however, the original texts of only two schools are available to us - the one in Pāli belonging to the Theravāda school and the one in Sanskrit recognized to be a Mūlasarvāstivāda version. The latter text was found in 1931 in the form of a manuscript enclosed within a stūpa in Naupur near Gilgit, present-day North Pakistan. This manuscript was investigated, analysed, compared with the Tibetan version and translated into German by Hu-von Hinüber. Hu-von Hinüber 1994. There also exist several small fragments of the Sanskrit texts of the Poṣadhavastu attributed to the Sarvāstivāda school. Hu-von Hinüber 1994: 78-84.

21 Hu-von Hinüber 1991: 746.

22 The Poșadhavastu comprises the second chapter of the Tibetan version of the Vinayavastu included in the Kanjur. Ui et al. 1934: 1, $\mathrm{N}^{\circ}$ 1. The Tibetan translation of the Poșadhavastu (Tib. gso sbyong gi gzhi) is the only existent full version of this treatise belonging to the Mūlasarvāstivāda tradition. The Sanskrit manuscript from Gilgit has not been preserved in full while the Chinese translation of this version, if there ever was one, has not survived to the present. The Tibetan translation corresponds generally to the Gilgit manuscript. Hu-von Hinüber 1994: 65-66, 72. 
included in the $s D e$ dge redaction of the Kanjur ${ }^{23}$ offers the following translation of the fragment regarding the five types of the gandīi:

Therefore, as regards that gandī, there are five types: the gandī for gathering monks together, the gandī for communal sittings, the gandị of the dead, the gandị of the renunciation and the gandī for the dangerous situations. ${ }^{24}$

Another classification of the gaṇdī can be found in the Kriyāsamgrahanāma, the Tibetan translation of which is included in the Tibetan Tanjur. ${ }^{25}$ About four types of the gandi $\bar{\imath}$ that are associated with the fourfold tantric practice of nirvedha-bhāgìya and its four stages which are "heat" (Tib. drod; Sanskr. ușmagata), "summit” (Tib. rtse mo; Sanskr. mūrdhāna), "patience” (Tib. bzod pa; Sanskr. kșānti) and "the highest worldly dharma" (Tib. chos kyi mchog; Sanskr. laukikāgrya-dharma), ${ }^{26}$ the text states the following:

Then the small gandịi, completely purified by the meditative heat. [...] Also the second gaṇdī, completely purified by the clear realization of the summit. [...] Also the third gandī, completely purified by the patience. [...] Similarly the fourth gandī, completely purified by the highest worldly dharmas. ${ }^{27}$

23 As a part of the Kanjur the Vinayavastu has been translated into Mongolian and can be found in the Li $\gamma$ dan qayan manuscript redaction (1628-1629) as well as the Kangxi xylographic redaction (1717-1720) of the Mongolian Kanjur under the title Nomoyadqaqui-yin sitügen (alter-

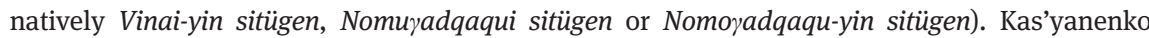
1993: 182-187, N 599-602; Ligeti 1942: 306-309, N 1125-1129.

24 'di ltar gaN+DI de ni lnga ste/dge 'dun bsdu ba'i dang/las kyi gaN+DI dang/shi ba'i gaN +DI dang/spong ba'i gaN+DI dang/gnod pa byung ba'i gaN+DI'o/PV: 136a1-2. Compare with the Sanskrit version and the translation by Hu-von Hinüber. Hu-von Hinüber 1991: 746.

25 In the sDe gde edition of the Tibetan Tanjur, the text is placed in the Ku volume of the Tantra (Tib. rgyud) section. The colophon to the treatise names Rigs kyis byin, or Kuladatta, as its author and Kïrticandra and Yar lungs pa grags rgyal mtshan as its translators into Tibetan. Lokesh Chandra 1992-1994: 1851; KrS: 362a6-7; Ui et al. 1934: 389. Although the text itself represents an important source of various ritual practices, the author's identity remains unclear. According to scholars' tentative estimations, he was active in the second part of the eleventh century. The practices he documented in his treatise may therefore also be dated at least to the same period, with a high degree of probability that they had been used at some earlier time. Rospatt 2010: 197-198, n. 1, 2.

26 KrS: 346a2-6; Sakaki 1925: 93; Tanemura 1993: 1123. On the practice of nirvedha-bhāgiya, see, for example, Gethin 1998: 188, 196-197; Tenzin Gyatso 2000: 107-108.

27 de nas drod rnam par dag pa gaN+DI chung ba ni [...]/de bzhin du rtse mo mngon par rtogs pa'i rnam par dag pa gaN+DI gnyis pa ste/[...]/de bzhin du bzod pa’i rnam par dag pa ni gaN+DI gsum pa ste/[...] de bzhin du chos mchog gi rnam par dag pa ni gaN+DI bzhi pa ste/ KrS: 346a3-6. 
The text does not explain the grounds for drawing this parallel between the stages of the nirvedha-bhāgìya and the types of the gandīi. The primary principle of this classification remains unclear. Along with the list of the types of gandi, the text also provides the measurements for the length and circumference of all four of these types. These measurements, which I will discuss later in detail, are not given as bare figures but are associated with particular Buddhist concepts. However, the source does not specify what the connection is between these concepts and the stages of the nirvedha-bhägiya practice, and whether they are related at all.

\section{Physical features}

\subsection{As specified by textual sources}

The analysis of the physical features of a studied artefact or the "substantial analysis" constitutes the basis for research conducted within the frameworks of material culture studies. The description of physical features includes firstly an account of measurements, material and the so-called "content" of an artefact, according to which various decorative or symbolic motifs and inscriptions should be understood. ${ }^{28}$

I did not succeed in finding any scientific substantial analysis of an actual ganḍ̄ beam dating to the more-or-less remote past. Artefacts currently available in modern Buddhist monasteries in Tibet or Mongolia, for example, are not known to have been subjected to this type of scientific examination by contemporary scholars.

What we have in abundance, on the other hand, are normative guidelines for the gandì beam production. These guidelines generally state the materials suitable for the creation of the gaṇi $\grave{i}$ and the precise measurements of not only the gaṇ̣̂i itself, but also of a stick used as the gaṇ̣̂̀-striker.

Another source provides us with notions of the possible appearance of the gandì and its physical features. These are the beam's visual representations, found on a multitude of Buddhist thangkas and on other religious images.

The primary material for the gaṇ̣i production appears to have always been wood. Referring to Chinese sources, Hu-von Hinüber and Staël-Holstein note that in the Chinese tradition, the gandi could have been produced from other materials such as metal or stone. ${ }^{29}$ Textual materials confirming the application

28 Prown 1982: 7-8.

29 Hu-von Hinüber 1991: 739-740; Staël-Holstein 1913: XXII, n.1. 
of similar variations in the gandì-making process in the Tibetan-Mongolian Buddhist tradition have not been found to date.

For my analysis, I discovered four original sources offering practical prescriptions for the production of the gandī. These texts date to different time periods and possess different genre affiliations. The first of these, the Gandīsūtra or gaN DI'i mdo, ${ }^{30}$ contains the following passage enumerating 16 types of trees suitable for creating the gaṇịi:

Sandal, Bengal quince, ${ }^{31}$ bastard teak, ${ }^{32}$ sacred fig, ${ }^{33}$ red sandal, Mespilus cotoneaster, Palmyra tree, bastard teak, aloe wood, false mangosteen, ${ }^{34}$ mango tree, walnut tree, gooseberry, ${ }^{35}$ tintisara and ashoka. If all of them are absent, it should be diligently made from mulberry. ${ }^{36}$

The Tibetan translation of the Kriyāsamgrahanāma, which has already been noted above, states five types of trees from which the gandị should be made:

It should be made from trees such as Cassia sophora, ${ }^{37}$ banyan, sacred fig, Ceylon ironwood, ${ }^{38}$ and cluster fig tree..$^{39,40}$

Yet another list of trees that constitute proper material for the gandī can be found in the manual to the ritual of the purification of vows, titled Bslab pa yongs su sbyong ba’i gzhi gsum gyi cho ga la sogs pa so sor thar pa'i blang dor gyi

30 A Mongolian translation of the sūtra under the title Gandi-yin sudur has been included in the Li $\gamma d a n$ qayan manuscript redaction (1628-1629) and the Kangxi xylographic redaction (17171720) of the Mongolian Kanjur. Kas'yanenko 1993: 244, $\mathrm{N}^{\circ} 796$; Ligeti 1942: 286, $\mathrm{N}^{\circ} 1058$. As a part of this canonical collection the text has been transmitted in Mongolia. I am not aware of any separate Mongolian redactions of the text having been in circulation or in use in the Mongolian Buddhist monasteries.

31 Aegle marmelos.

32 Butea frondosa.

33 Ficus religiosa.

34 Xanthochymus pictorius.

35 Emblica officinalis.

36 tsan dan bil ba pa la sha// a shwad tha dang tsan dan dmar// rgya star (3) ta la king shu ka// shing sha pa dang ta ma la// a mra star bu skyu ru ra// tin ti sa ra a sho ka//'di dag thams cad med na yang//'o se las ni 'bad de bya DGS: 302b2-3.

37 This identification is tentative and is derived from phonetic resemblance of the Tibetan $k A$ shA rI, found in the text, and the Sanskrit kāsari defined as Cassia sophora by the MonierWilliams dictionary. Monier-Williams 1974: 281.

38 Mesua ferrea. This is a possible identification based on the phonetic similarity of the Tibetan ke shar to the Sanskrit kesंari or kesara. Monier-Williams 1974: 310-311.

39 Ficus racemosa.

40 de yang $k A$ shA rI dang/nya gro $d+$ ha dang/a shwa d+tha dang/ke shar dang (3) $u d u$ $m+w A$ ra'i shing rnams las bya'o KrS: 346a2-3. 
gnas mams mdor bsdus pa and composed by 'Dul ba 'dzin pa grags pa rgyal $\operatorname{mtshan}^{41}$ :

As for the gandīi, [it should be made] from mulberry tree provided there is no white and red sandal, Bengal quince, bastard teak, Mespilus cotoneaster, or ashoka. ${ }^{42}$

The same list can also be found in the Bslab pa yongs su sbyong ba'i cho ga sdom brtson dgyes byed, written by Ching su tsug thu no mon han blo bzang nor bu shes rab. ${ }^{43}$ Closer analysis immediately revealed that the entire passage devoted to the description and implementation of the gandī was borrowed by Blo bzang nor bu shes rab from the treatise by Grags pa rgyal mtshan and was cited directly without indicating the original source. ${ }^{44}$

Out of the three texts noted above, the enumeration from the Gandīsūtra might be the earliest and most detailed. Included in the text that has become a part of the Tibetan Kanjur collection, this enumeration seems to have gained normative status. It has also been cited by other Tibetan authors writing about the gaṇdì beam. ${ }^{45}$

The list from the Kriyāsamgrahanāma is the shortest and most peculiar. It obviously does not follow the tradition established or transmitted by the Gandịisūtra.

The latter two examples show us what the main line of the gandi presentation in the monastic dGe lugs pa tradition was. They also allow us to presume that this tradition was likely transmitted to Mongolia and further cultivated there.

All four of the aforementioned sources also contain some information on the measurements of the gaṇi beam and details of its appearance, as well as the form and size of the gandì-striker. However, the content and the way in which the four sources present the information differ significantly from one text to another. Thus, the Gandīisutra states the following:

As for the measurements, make the smallest to be 84 of the eight fingers. As to the fingers in breadth, make it six. In height also make it two. Measuring in finger joints, the size on the

41 'Dul ba 'dzin pa grags pa rgyal mtshan (1374-1434) is considered to be one of the most important $d G$ e lugs $p a$ teachers. He was one of the main direct disciples of Tsong kha pa. The scholar was especially known and respected for his writings on Vinaya. TBRC: P1591; http:// www.treasuryoflives.org/biographies/view/Duldzin-Drakpa-Gyeltsen/2891.

42 gaN+Di ni/rgyu tsaN+Dan dkar dmar dang/bil ba dang ba la sha dang/rgya star dang/a sho ka 'am/med na 'o ma si’i shing la Grags pa rgyal mtshan: 2.

43 Ching su tsug thu no mon han blo bzang nor bu shes rab (1677-1737) was a dGe lugs pa teacher who was active in Mongolia. Not a lot is known about his life and work. His main place of residence was the dGe ldan bshad sgrub bstan 'phel gling monastery. TBRC: P411.

44 Cho ga: 2a3-4a2.

45 See, for example, dGe 'dun grub pa: 118b2-3 or Dung dkar: 482-483. 
four edges is two. The perfect evenness is made very evident. Both ends are similar to the frog's head. Then also the striker should be cut from the same wood. Measuring 12 fingers, it is round and with the mongoose heads at both ends. The size of the handle is also like that. ${ }^{46}$

The Kriyāsamgrahanāma provides four different sizes for the gandī, corresponding to the four types of instruments distinguished by the text. All measurements are associated with different Buddhist doctrinal concepts. The first gandī, related to the "heat" stage of the nirvedha-bhägiya practice is described thus:

In length - the purity of the 84 collections of dharma ${ }^{47}$ - three of the 84 parts. Due to the 12 elements of the interdependent origination ${ }^{48}$ it is round having 12 parts in circumference. $^{49}$

The second gandī, related to the "summit" stage of the nirvedha-bhāgìya practice is described thus:

In length - the five higher perceptions ${ }^{50}$ and marks of excellence -85 . Due to the purity of the 13 stages $^{51}-13$ parts [in circumference] and round. ${ }^{52}$

The measurements of the third gandī, related to the "patience" stage of the nirvedha-bhāgìya practice are presented thus:

In length - the purity of the 10 strengths, 10 merits, 10 powers, 10 pāramitās, 10 cognitions, and the 37 accessories of enlightenment ${ }^{53}-87$ parts. In circumference 15 parts - the purity of the 15 vowels such as those of an unobscured type and others. Because of the 12 kinds of the Buddha's teachings ${ }^{54}-82 .{ }^{55}$

46 tshad ni chung ngu sor brgyad kyi// brgyad cu rtsa bzhi nyid bya zhing// zheng du sor ni drug bya ste// 'phang du yang ni gnyis bya'o//sor mo'i tshigs kyi tshad dag gis// zur bzhir tshad ni gnyis pa yin// legs mnyam nyid ni shin tu gsal/(7)/rtse gnyis sbal pa’i mgo bzhin no// de nas rdung bar byed pa yang// shing de nyid las bcad de bya// sor bcu gnyis kyi tshad dag la// zlum zhing rtse gnyis ne’u le'i mgo// chang zungs tshad kyang de bzhin te DGS: 302b6-7.

47 Dharmaskandha (Sanskr.).

48 Pratityasamutpāda (Sanskr.).

49 chos kyi phung po brgyad cu rtsa bzhi'i mam par dag pa cha brgyad cu rtsa bzhi pa gsum ste srid du'o// rten cing 'brel bar 'byung ba'i yan lag bcu gnyis kyi rnam par dag pas khor yug tu cha bcu gnyis (4) te zlum po'o KrS: $346 \mathrm{a}$.

50 Abhijña $\bar{a}$ (Sanskr.).

51 Bhūmi (Sanskr.).

52 mngon par shes pa lnga dang dpe byad bzang po brgyad cu rtsa lnga ste srid du'o//sa bcu gsum gyi rnam par dag pas cha bcu gsum pa ste zlum po'o KrS: 346a.

53 Bodhipākșikadharma (Sanskr.).

54 Dvādaśāñgapravacana (Sanskr.).

55 stobs bcu dang dge ba bcu dang dbang bcu dang pha rol tu phyin pa bcu dang shes pa bcu dang byang chub kyi phyogs kyi chos sum cu rtsa bdun gyi mam par dag pa cha brgyad cu rtsa bdun te 
The measurements of the fourth and the biggest gaṇī related to the "highest worldly dharmas" stage of the nirvedha-bhāgiya practice are explained as follows:

Due to the purity of abolishing the 98 afflictive emotions 98 parts in length. The purity of the 18 distinctive qualities of the buddhas ${ }^{56}-18$ parts in circumference. Due to the purity of the 16 truths $-86^{57}$

The beam's striker is characterized by the treatise thus:

It is necessary to tell about the size of the gandi-striker: its upper section has ten parts - the purity of the 10 female spiritual consorts. It is round having six parts in circumference the purity of the six recollections. ${ }^{58}$ Below it is round similarly to the five pristine cognitions. The purity of the five accumulations. ${ }^{59}$

The Kriyāsamgrahanāma contains one more passage regarding the form of the instrument. The details provided by this fragment are found neither in the Gandīisūtra nor in the work by Grags pa rgyal mtshan. It reads as follows:

One part that is the middle one of the upper five parts of all types of the gandi should be hollowed out. It should be cut one part deep all around. The purity of the five aggregates transcending the physical world. On this, due to the purity of the seven highest offerings, there are seven decorative paintings. From among these make whichever you like. ${ }^{60}$

The Bslab pa yongs su sbyong ba'i gzhi gsum gyi cho ga la sogs pa so sor thar pa’i blang dor gyi gnas rnams mdor bsdus pa by Grags pa rgyal mtshan also contains a passage that provides information on the size of the beam and its striker ${ }^{61}$ :

(6) srid du'o// sgrib pa med pa’i mam pa la sogs pa’i dbyangs bco lnga’i mam par dag pa cha bco lnga ni zlum po'o// gsung rab yan lag bco gnyis kyi dag pas brgyad cu rtsa gnyis so KrS: 346a.

56 Āvenikabuddhadharma (Sanskr.).

57 nyon mongs pa dgu bcu rtsa (7) brgyad spangs pa’i rnam par dag pas cha dgu bcu rtsa brgyad srid du'o// sangs rgyas kyi chos ma 'dres pabco brgyad mam par dag pa 'khor yug tu cha bco brgyad do// bden pa bcu drug gi rnam par dag pas brgyad cu rtsa drug go KrS: 346a.

58 Anusmrti (Sanskr).

59 gaN+DI thi'u'i tshad brjod par bya (3) ste/de la steng gi cha la cha bcu ste gzungs ma bcu'i rnam par dag pa'o// khor yug tu cha drug gis zlums te ries su dran pa drug gi mam par dag pa'o// 'og tu ye shes lnga de dang mtshungs pa'i zlums so// phung po lnga'i dag pa'o/KrS: 346b2-3. 60 gaN+DI thams cad kyi yar cha lnga'i dbus kyi cha gcig dma' par bya'o// (2) khor yug tu cha gcig gis dman pa'o//'jig rten las 'das pa’i phung po lnga'i mam par dag pa'o// de la blan med pa'i mchod pa bdun rnam par dag pas tshon ris bdun no// 'di rnams kyi nang nas yid la gang 'tshad pa de bya'o/KrS: 346b1-2.

61 Although the Bslab pa yongs su sbyong ba'i cho ga sdom brtson dgyes byed by Ching su tsug thu no mon han blo bzang nor bu shes rab also contains a passage with such information, it is not cited here, because it directly repeats the treatise by Grags pa rgyal mtshan. 
The size of the biggest is 108 fingers. The smallest has 84. In breadth six fingers. In height two fingers. At the four edges it has the size of two fingers. The ends are like the head of a frog. The striker is cut from the same wood. The size is 12 fingers. Round with the ends looking like the head of a mongoose. The size of the handle is also equal to that. ${ }^{62}$

The fragments of the three treatises show that, with regard to the size and form of the gandịi, the Gandīsūtra and the manual by Grags pa rgyal mtshan belong to the same tradition. The latter text, in fact, transmits very closely the content of the sūtra and paraphrases it slightly. The only major difference between them is that the manual mentions the big-sized gandī, which measures 108 fingers, while the suttra does not. The measurements given for three dimensions and four edges ${ }^{63}$ let us understand that the texts describe an object that is an octagonal prism. The form of the striker, in turn, appears to be a cylinder with no numbers given to determine the circumference of its base.

The data provided by the Kriyāsamgrahanāma create a picture of a gaṇī that is essentially different from the two other descriptions. In the case of all four types of the instrument that it mentions, the text specifies only two parameters, i.e., length (Tib. srid) and circumference (Tib. 'khor yug). Such specifications lead us to the conclusion that according to the Kriyāsamgrahanāma, the gandī was supposed to have a cylindrical form. As to the striker, although the description is not easily intelligible, it definitely depicts the instrument in an entirely different way than the two other sources. It is at variance with these sources regarding all the parameters of the striker - its length, circumference, form and even decorations, as it does not mention any of them adorning the ends of the tool. It is also worth mentioning that, describing the size of the instruments, the Kriyāsamgrahanāma uses different units of measurement. While both the Gandīisuttra and the manual by Grags pa rgyal mtshan provide the sizes of the gaṇūi and its striker in "fingers" (Tib. sor), the Kriyāsamgrahanāma defines them in "parts" (Tib. cha). Interestingly all three texts are not in agreement as regards the terminology when they speak about the gandị-striker. The Gandīsūtra uses the phrase rdung bar byed pa to designate it. In the Kriyāsamgrahanāma it is

62 tshad rab mchur sor brgya rtsa brgyad/tha ma brgyad cu rtsa bzhi/zheng sor drug pa/dpangs su sor gnyis pa/zur bzhir sor gnyis kyi tshad dang ldan pa/rtse mo sbal ba'i mgo bo 'dra ba/gaN g. yog shing de nyid las bcad pa/sor bcu gnyis kyi tshad/zlum po rtse mo gnyis ne'u le'i mgo 'dra ba/ 'chang zung kyi tshad kyang de dang mnyam pa'o Grags pa rgyal mtshan: 2.

63 I believe that the phrases zur bzhir tshad ni gnyis pa yin and zur bzhir sor gnyis kyi tshad dang ldan pa of the Gandisisutra and the manual by Grags pa rgyal mtshan respectively refer to the edges of the beam and mean that these edges should be cut so as to create four faces, the width of which is to measure two fingers. Therefore, the measurements of the three dimensions, that is, length, width and height give us a picture of a parallelepiped. Supplemented with cut edges, the parallelepiped is transformed into an octagonal prism. 
called gaN $+D I$ thi'u, while the term gaN g.yog is applied in the treatise by Grags pa rgyal mtshan.

In terms of the physical features of the gandī, we should pay special attention to what Prown called the "content" of an artefact, that is, to decorations or inscriptions of any kind. ${ }^{64}$ The passages from the Tibetan translation of the Gandīsūtra and the manual by Grags pa rgyal mtshan cited above both mention specific decorations placed on both ends of the gandi $\bar{\imath}$ and the beam's striker. The texts are in accord with one another concerning the appearance of these decorations, which are in the form of the head of a frog in the case of the beam itself and a mongoose head in the case of the striker. The choice of decorative motifs is not clear. The texts provide no explanation for these symbols, nor any legends narrating the circumstances of their becoming a part of the gaṇ̣̂ ornamentation. The Kriyāsamgrahanāma also instructs making the ends of the gandi in the form of a frog's head. Its description, however, is more precise in terms of measurements. It also provides a type of explanation as to the application of this particular ornament:

At the end of the four types of the gandi the head of a frog ${ }^{65}$ measuring two, three, three and a half or four parts should be made. Manda - the core or the essence, that is, the pristine cognition of the complete awakening of a frog is to be expressed with the frog's voice. ${ }^{66}$

The text also gives more exact information about the decorative paintings mentioned as ornaments of the hollowed part of the beam:

Then it is necessary to speak about the successions of colors of the decorative paintings: they are the collection of four - yellow, red, green and blue. Therefore, yellow is the Mahāsāmghika, red is the Sarvāstivāda, green is the Sammitīya, blue is the Sthaviravāda. ${ }^{67}$

The Gaṇ̣īsūtra contains a passage that also refers to seven ornaments:

64 Prown 1982: 8.

65 Maṇūka (Sanskr.) - a frog. Monier-Williams 1974: 776.

66 gaN+DI rnam pa bzhi la rtse mo ru cha gnyis dang cha (346b1) gsum dang phyed dang bcas pa'i cha gsum dang cha bzhi'i tshad kyi maN+Du ka'i mgo bo bya'o// maN+Da ma snying po'am gtso ste maN+Du ka'i rdzogs pa’i byang chub kyi ye shes ni maN+Du ka'i sgras brjod par bya'o/ KrS: 346a7-346b1.

67 de la tshon ris bdun gyi tshon gyi rim brjod par bya ste/ser po dang /dmar po dang/ljang gu dang/sngon po dang/bzhi tshogs pa dang rnams so//de la ser po ni dge 'dun phan chen po'i 'o/ /dmar po ni thams cad yod (7) par smra ba'i 'o/ /ljang gu ni mang pos bkur ba'i'o/ /sngon po ni gnas brtan pa'i'o/ KrS: 346b6-7. 
After that in every monastery it should be struck in the mode of the developing stage, ${ }^{68}$ in the same way as those adorned with the seven nāgas. ${ }^{69}$

Unfortunately I was unable to discover what type of decoration the text might refer to when speaking about the seven nāgas. It is also not quite clear whether the gandi itself is meant to possess this ornamentation. The manual by Grags pa rgyal mtshan does not repeat or specify information about any decorative motifs. I also found it difficult both to draw any parallels between the seven ornaments mentioned by the Kriyāsamgrahanāma and these seven nāgas and to state whether the texts tell about the same type of decoration. As we can see from the relevant passages cited above, the relation or correspondence between the colour scheme and the decorative elements is not explicitly explained in the text.

\subsection{As depicted on images}

It is difficult to overestimate the role of images for studies conducted within a variety of humanistic disciplines, including cultural and historical anthropology, as well as historical studies. The testimonies of images are equally important for material culture studies and when available should necessarily be taken into consideration to fully understand the historical development of a particular tangible object. Although some images may function as direct historical evidence, such a straightforward purpose is certainly not the only one that they may serve. Speaking about the value of images for historical studies, Burke noted:

The uses of images in different periods as objects of devotion or means of persuasion, of conveying information or giving pleasure, allows them to bear witness to past forms of religion, knowledge, belief, delight and so on. Although texts also offer valuable clues, images themselves are the best guide to the power of visual representations in the religious and political life of past cultures. ${ }^{70}$

68 Bskyed rim (Sanskr. utpattikrama) is a specific meditative practice developed within the Vajrayāna, or the so-called Tantric Buddhism. It is one of the two main parts of the annuttarayogatantra. It represents the first stage of a twofold process. If passed successfully, it is to be followed by the perfection stage (Tib. rdzogs rim; Sanskr. sampannakrama). The practitioner is in this stage involved in the process of visualizing himself as the divine form of a deity and of his environment as the pure field of the mandala of the deity. Garab Dorje 1996: 28; Buswell/ Lopez 2014.

69 de 'og gtsug lag khang kun du// klu bdun gyis ni brgyan pa ltar// bskyed pa’i rim gyis brdung bar bya DGS: 303a2.

70 Burke 2008: 13. 
Not all images that I will examine here in connection with the history of the gaṇ̂̄ beam possess documental value. The majority of them are Buddhist religious paintings, the so-called thangkas, which portray the gandi $\bar{i}$ as an attribute of a certain Buddhist deity. Ruled by the established principles of Buddhist iconography, these images are highly symbolic and multilayered in terms of their conceptual content. The gandị beam is very likely to have never been actually created in the form in which it can be seen in these pictures. However, this does not undermine their importance for the understanding of the dynamics of the social reality that the gandī has been part of.

As Morgan asserts:

\begin{abstract}
What makes an image "religious" is often not simply its subject matter or the intention of the person who created it but the use of the image as well as the context of its deployment and interpretation. In every instance, the image is better understood as an integral part of visual practice, which is, properly speaking, a visual mediation of relations among a particular group of persons and the forces that help to organize their world. The medium of belief - using belief in the relational sense of a covenant and not merely assent to a proposition - is not only an image but also everything that a person or community does with and by means of an image. ${ }^{71}$
\end{abstract}

Applying such a practice-oriented discursive approach to the analysis of religious pictures containing images of the gandī, I seek to discover the way in which images may have influenced or modified the cultural context in which the gandì has been practically used and conceptually perceived.

In the Tibetan and Mongolian Buddhist tradition, the gandi beam is a regular attribute of the iconography of the protector deity Pañjara Mahākāla. In fact, the gandịi is a distinctive symbol of this particular form of Mahākāla. The tradition of this deity was brought to Tibet from India by the great Buddhist scholar and propagator of the Teaching in Western Tibet, Rin chen bzang po (958-1055). Pañjara Mahākāla was favoured by the Tibetan Sa skya pa school of Buddhism and became popular with the rulers of the Mongolian Empire during the thirteenth and fourteenth centuries, and later at the time of Li $\gamma$ dan qayan. For the Mongolian rulers, the deity appeared to be a symbol of Imperial strength and royal legitimacy. ${ }^{72}$

The Tibetan name of the deity is gur gyi mgon po. The Tibetan gur may be translated as "tent", ${ }^{73}$ while the entire name can be understood as "the protector

71 Morgan 2005: 55.

72 Berger 1995: 54-55; Rhie 2004: 47, 52; Beer 2003: 139-140; Grupper 1984: 52-54, 67-69. Relevant information on the topic can also be found in Grupper 1979. This work was unfortunately not available to me in the course of this article's preparation.

73 Das 1902: 222. 
of the tent". This erroneous translation was commonly accepted by scholars at the end of the $19^{\text {th }}$ and to the beginning of the twentieth century. ${ }^{74}$ This interpretation of the name might also have been the result of popular etymology disseminated among the bearers of the tradition themselves. In this way, popular etymology may have contributed to the belief that Pañjara Mahākāla was of Central Asian origin. The deity was therefore considered to be the patron of the nomadic people who dwelled predominantly in tents. ${ }^{75}$ In reality, it was the Sanskrit pañjara in the title of the Vajrapañjaratantra ${ }^{76}$ that came to be translated in Tibetan with the word gur. With pañjara meaning "a cage" or "a skeleton", 77 this form of Mahākāla was thought of as the lord of cemeteries and symbolically, as the deity who leads to the destruction of physical body attachment, which prevents humans from attaining the awakening. ${ }^{78}$ Huntington and Bangdel suggest that given the fact that Pañjara Mahākāla is "the lord of the exterior vajra enclosure, containing the whole Hevajra mandala palace and the charnel fields, the term gur is probably short for gur khang, a sacred pavilion". 79

Although the origin of Pañjara Mahākāla is difficult to trace, we can state with a high degree of certainty that the gandī which has become his distinctive attribute is a late addition to his iconography. As an argument for this hypothesis, Tucci suggests the fact that Mahākāla already had a specific object in each of his hands: a curved knife (Tib. gri gug; Sanskr. kartari) in the right and a scullcup (Tib. thod pa; Sanskr. kapāla) in the left. ${ }^{80}$ The gandị on the thangka images and in statuette form is placed horizontally across the two elbow pits of the arms, bent at the elbows.

Pañjara Mahākāla is a representative of the pantheon of the Tantric Buddhist tradition. A more rewarding approach would therefore be to understand how such a practical and routine instrument as the gandi became a distinctive feature of one of the most powerful transcendent protectors of Buddhism. One way toward this status might have already begun during the era of nikāya Buddhism. The functions of the gandī were very likely gradually turning from utilitarian to ritualistic. This means that the beam was no longer

74 Grünwedel 1900: 177; Waddell 1895: 70.

75 Beer 2003: 139. Schumann writes that, meaning “a cage”, pañjara refers to the carcase of nomadic tents. Schumann 1993: 196.

76 The Vajrapañjaratantra (Tib. rdo rje gur gyi rgyud) belongs to the Hevajratantra cycle and is classified as a non-dual annuttarayoga. Nientiedt 2007: 59.

77 Monier-Williams 1974: 575.

78 Tucci 1989: 124-127.

79 Huntington/Bangdel 2003: 335.

80 Tucci 1989: 124-127. 
struck for the purpose of actually gathering monks together or for informing them about important events. Its usage may have been integrated in a sequence of compulsory steps of certain communal procedures as a traditional, symbolic element already deprived of the majority of its pragmatics. Concurrently, the instrument gained ever more conceptual value as it became symbolically denser.

The fixation on the qualitative change concerning the notion of functional use to which the gandi $\bar{i}$ was supposed to be put occurred also in textual form. The Gaṇ̣̂isūtra, classified among the Mahāyāna sūtras, presents a vivid example of the completion of this process.

In the text of the sūtra, an extended passage explains a protracted range of powers with which the gandī was believed to be endowed:

It is the perfect protector of all sentient beings by the material embodiment of the sound of the Prajñāparamitā that is the mother of all sentient beings, the creator of buddhas and bodhisattvas worshiped, revered, contemplated and practiced by śrāvakas, pratyekabuddhas, and samyaksambuddhas; the total destroyer of all the tirthikas; the pacifier of all angry thoughts; the suppressor of sinful thoughts; the perfect clearer of aggressive thoughts; the eminent destroyer of the delusive thoughts; the complete banisher of the lustful thoughts; the excellent protector of the bodhicitta; the encourager of the thoughts about awakening; the attender of the Buddha appearance; the pacifier and destroyer of all fights, splits, quarrels, arguments, sufferings, bad dreams; the subduer of incidental diseases and deaths; the subduer of the untimely deaths, droughts and others; the pacifier of the hostile armies; the perfect destroyer of demons; the dispeller of torments; the efficient multiplier of the great fortune; the bestower of long life without diseases; the queller of the fear of death; the expander of freedom and auspiciousness; to those who heard it and rejoiced [it is] the real bestower of the results like the wish-fulfilling gem. The mother, the Prajñāpāramitā resides in the form of the gandị̄. ${ }^{81}$

81 'di ni sems can thams cad kyi ma sangs rgyas dang/byang chub sems dpa' skyed pa/nyan thos dang/rang sangs rgyas dang/yang dag par rdzogs pa'i sangs rgyas thams cad kyis phyag (4) byas pa/mchod pa/bsams pa/bsgoms pa/shes rab kyi pha rol tu phyin pa sgra'i gzugs kyis sems can thams cad yongs su skyong bar byed pa/mu stegs pa thams cad rnam par 'jig par byed pa/sdang ba'i sems 'dul bar byed pa/sdig pa'i sems 'joms par byed pa/zhe sdang ba'i sems rnam par (5) sel bar byed pa/gti mug gi sems rab tu 'jig par byed pa/'dod chags kyi sems mam par spong bar byed pa/byang chub kyi sems yongs su skyong bar byed pa/sangs rgyas kyi sems 'phel bar byed pa/ sangs rgyas 'byung ba bsten par byed pa/'thab pa dang/'gyed pa dang/'khrug pa dang/rtsod pa dang/(6) sdug bsngal ba dang/rmi lam ngan pa dang/kun 'dul ba thams cad 'jig par byed pa/glo bur gyi nad dang/'chi ba zhi bar byed pa dang/dus ma yin par 'chi ba dang/ri mas la sogs pa zhi bar byed pa/pha rol gyi dpung 'dul bar byed pa/bdud mam par 'jig par byed pa/gdung ba sel bar byed pa/skal ba (7) bzang po yang dag par 'phel bar byed pa/tshe dang nad med pa ster bar byed pa/'chi ba'i 'jigs pa zhi bar byed pa/thar ba dang dpal 'phel bar byed pa/gang gis thos nas rjes su yi rang ba de la yid bzhin gyi nor bu ltar 'bras bu rab tu ster ba/yum shes rab kyi pha rol tu phyin pa gaN DI’i (302b1) gzugs kyis bzhugs so zhes thos pa dang/DGS: 302a3-302b1. 
Having been involved in the elaborated structure of the profound Mahāyāna philosophy, the gandi came to be closely associated with its central and most powerful concept, that of the Prajñāparramitā. As a physical embodiment of the Prajñāpāramitā, the gaṇụi was no longer treated as a mere wooden idiophone calling monks to gather together, but as a sacred religious item, an object of reverence and worship.

Other sources referring to the gandī also contain passages which mention the relationship between the beam and the Prajñāpāramitā and its consequences. The Kriyāsamgrahanāma reads as follows:

Through the sound of the gandī being struck the voice of the Prajñāpāramitā is being naturally uttered. By the sound of the gaṇī being struck benedictions will be pronounced. In the monastery in which the gandi is struck monks and nuns, male and female lay followers will completely overcome all the illnesses. They will become entirely awakened. $^{82}$

Grags pa rgyal mtshan notes only a couple of sentences in this regard:

As the gandī expresses the essence of the Prajñāpāramitā, it should be venerated very much. In the same text it is said - the mother Prajñāpa aramitā resides in the form of the gandịi. ${ }^{83}$

Thangkas and statuettes that present Pañjara Mahākāla and originate from Tibet and Mongolia have been preserved in abundance. ${ }^{84}$ They date to different time periods and represent various styles of fine art. Of course, we cannot judge the material and precise size of the gandi from these images of the deity. Nonetheless, they may be used as sources of information about the content of the beam and its form.

The content of the gandis encountered on the images is quite varied. The ornamentation often covers the entire length of the beam and is sometimes simply a floral or geometrical motif. In other cases, the images of several fortress gateways that are believed to conceal the armies of gods and asuras are depicted on the body of the beam. The ends of the gandi $\bar{l}$ as they are shown in religious images are also shaped in different ways, taking the form of vajras, lotus-

82 gaN+DI brdungs ba'i sgras shes (4) rab kyi pha rol tu phyin pa'i sgra'i rang bzhin du brjod par 'gyur ro// gaN $+D I$ brdungs ba'i sgras bkra shis kyi tshigs su 'byung bar 'gyur ro// gang du gaN+DI brdungs ba'i gtsug lag khang de ru dge slong dang dge slong ma dang dge bsnyen dang dge bsnyen ma nad thams cad nye (5) bar zhi bar byed do// byang chub tu yongs su 'gyur bar byed do//KrS: 346b3-5.

83 gaN +Di ni yum sher phyin gyi ngo bor gsungs pas shin tu gus par bya ste/de nyid las yum shes rab kyi pha rol tu phyin pa gaN+Di'i gzugs kyis bzhugs so zhes so/Grags pa rgyal mtshan: 5 .

84 For examples, see http://www.himalayanart.org/search/set.cfm?setid=265\%26page=1 or Rhie 2004: 46-91. 
mounted jewels or scrolling makara-tails. ${ }^{85}$ Investigation of the images leads us to the conclusion that the manner of depicting the gandi has not been very strictly determined, or that a number of traditions for its presentation existed. This is important to highlight that, as an attribute of Pañjara Mahākāla, the gaṇ̣̂ was generally depicted in a richly adorned form (see Figure 2).
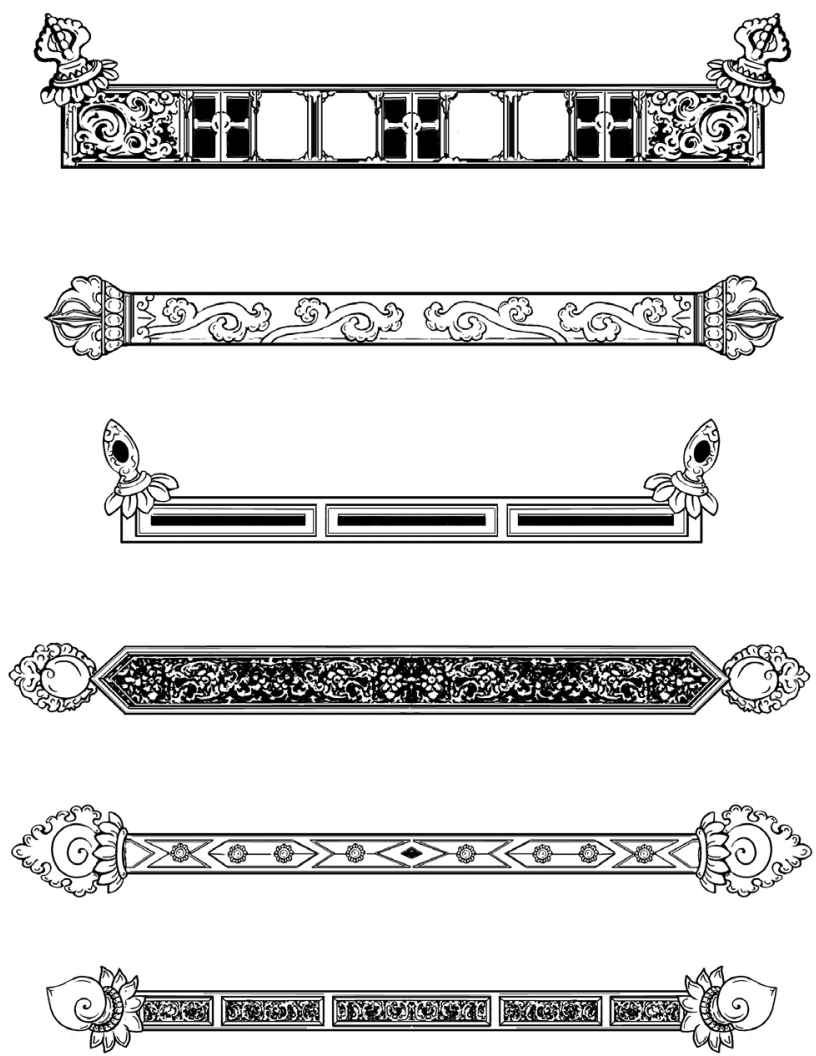

Figure 2: Different forms of iconographic representation of the gandīi beam. ${ }^{86}$

The two dimensional images of the thangkas do not allow us to state with certainty what the exact form of the beam is. The gandi is depicted on them as

85 Beer 2003: 140; Willson/Brauen 2000: 564.

86 The illustration is made by P. Sobkowiak on the basis of the material provided by Beer and original Tibetan thangkas, available via himalayanart.org. Beer 2003: 139; http://www.himala yanart.org/search/set.cfm?setID=265. 
a long and narrow rectangle, the width of which is in most cases the same along the entire length.

Interestingly, the visual representations of the gandi found on the images of Pañjara Mahākāla, although generally pertaining to the same tradition of Tantric Buddhism, do not resemble the descriptions of the beam included in the Kriyāsamgrahanāma.

The history of Pañjara Mahākāla visual representation in Mongolia has not yet been thoroughly studied. Yet in my investigation I came across visual evidence testifying to the special attention that has been devoted to the gandi as a characteristic feature of Pañjara Mahākāla in the Mongolian Buddhist tradition. One of the colour images, with which a manuscript copy of the Mongolian Kanjur preserved in the Institute of Mongolian, Buddhist and Tibetan Studies of the Siberian Branch of the Russian Academy of Sciences, Ulan-Ude, Buryatia, Russian Federation is illuminated, provides a typical iconographic representation of Pañjara Mahākāla. Remarkable is a title written in classical Mongolian in golden ink. The title reads gandi maq-a kala. ${ }^{87}$ Being principally defined by the presence of the gandi among its attributes, in this case Pañjara Mahākāla even borrowed his name from the instrument. The data currently available to me are not sufficient to draw any further conclusions about this specific designation. Further research is needed to establish whether the deity has been commonly known under this name in Mongolia or the example provided by the Kanjur illustration is rare and possibly pertains to some particular tradition.

\section{Manipulations of the gaṇ̣ī}

\subsection{Modes of striking the gandi}

First and most basic among the functions of the gandī is its striking. We may assume that initially this used to be a simple procedure, the major goal of which

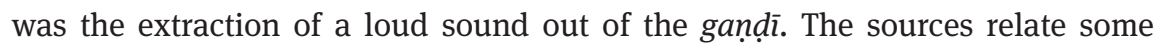
special modes of striking, the application of which depended on the occasion for which the beam was used. Original texts are not in accord with regard to these special occasions. As I mentioned earlier, the Poșadhavastu presents five such

87 The image can be found on the last page (373a) of the volume 23 ('a) of the Dandir-a section of the Kanjur. I would like to express my gratitude to Nikolai Tsyrempilov, who found the picture and made it available to me. 
occasions, which correspond to the five types of the gandi distinguished by the text. The beam is reported to have been struck differently on these five occasions:

Therefore the gandī for gathering monks together [is struck in] three successions and three hard strokes. ${ }^{88}$ The gandī for communal sittings [is struck in] one succession and three hard strokes. The gaṇdī of the dead [is struck as] an unadorned one. ${ }^{89}$ As the gandī of the renunciation a beggar's staff ${ }^{90}$ [is struck]. The gandị for the dangerous situations [is struck] until it is enough. ${ }^{91}$

In the treatise by the first Dalai Lama Dge 'dun grub pa (1391-1474), titled Legs par gsungs pa'i dam pa'i chos 'dul ba mtha' dag gi snyig po'i don legs par bshad pa rin po che'i 'pheng ba zhes bya ba'i smad cha la shog grags, we find a detailed commentary on the abovementioned five modes of striking the gandī. The text in the most part agrees with the Tibetan version of the Poșadhavastu. However, it also provides additional information about different traditions of striking for the second, third and fourth occasions:

\begin{abstract}
In order to gather the entire monastic community together at the time of a big assembly three successions and after them three loud strokes are to be made. As to the striking of the gandị in order to perform the duties - one succession and three hard strokes. From some other tradition, it is known that in order to perform the duties - three successions and two hard strokes. As to the gandī being struck for taking away the corpse of the dead on the shoulders - an unadorned one, that is, it should be struck in successions for a short time and after that no hard stroke is to be given. According to some other tradition, when the gaṇī is struck for the dead, it is one succession and one hard stroke. In order to gather the renunciants the gandi ${ }^{\prime}$ s task is fulfilled with a mendicant's staff. According to some other tradition, the small gaṇdi is struck for the renunciants. When the ganḍi is
\end{abstract}

88 There is a difference in the transmission of this particular mode of striking the gandi between the Sanskrit and Tibetan texts of the Poșadhavastu. According to the Sanskrit version, when using the gandī for calling the monks to communal sittings (Sanskr. karmagandīi Tib. las kyi gaN $+D I$ ), it should be struck in three successions of strokes and two strong strokes. According to the Tibetan text, the number of successions in this case is one and the number of strong strokes is three. Hu-von Hinüber 1991: 748; PV: 136a2.

89 The Tibetan byi bo corresponds here to the Sanskrit mundikā. Hu-von Hinüber equates the form muṇika $\bar{a}$ with munda and considers that the Tibetan iteration was intended to convey the first meaning of the latter, namely, "shaved, bald". Monier-Williams 1974: 822; Hu-von Hinüber 1991: 751. I suggest taking into consideration such meanings of the Sanskrit word as "stripped of top leaves or branches, lopped (as a tree), the trunk of a lopped tree". Monier-Williams 1974: 822. 90 Also 'khar gsil (Sanskr. khakkhara). Monier-Williams 1974: 334; Hu-von Hinüber 1994: 292-293. 91 de la dge 'dun bsdu ba'i gaN+DI de ni rgyud gsum dang tog gsum mo// las kyi gaN+DI de ni rgyud gcig dang tog gsum mo// shi ba’i gaN+DI de ni byi bo'o// spong ba’i gaN+DI de ni khar sillo// gnod pa byung ba’i gaN+DI de ni ji tsam gyis chog pa'o/ PV: 136a2-3. 
struck at the time of hail and similar dangerous occasions, it should be struck until it is enough. ${ }^{92}$

The text specifies at least one more occasion on which the ganḍi is to be used:

In order to gather the monks for a meal the gandị and the small gandị is struck. ${ }^{93}$

The text also contains the instructions for where the beam should be placed or kept in the monastery, by whom and how exactly the successions and hard strokes should be performed:

As to the place of keeping the gandī, put it in some ascended place like above the monastery gates or so. As to the performer of the striking, it is struck by somebody keeping at least the vows of an upassaka. As to the way of striking, he should come up to the roof of a granary or other elevated place and at first bow to the three jewels and make three shangs tsha. ${ }^{94}$ After that three successions and three very loud strokes are done or alternatively three successions and two strokes are performed. In every succession there are 35 strokes. 108 strokes are made in the same way as with the full moon. ${ }^{95}$

92 'dus pa chen po'i tshe dge 'dun thams cad bsdu ba'i phyir ni// rgyud gsum dang de nyid kyi mjug tu tog sgra chen po lan gsum bya'o// las bya ba'i don du gaN+DI (3) brdung ba ni rgyud gcig dang tog gsum mo// lugs kha cig las ni las bya ba'i don du rgyud gsum dang tog gnyis shes'o// shi ba la phrag pas phung po dbyung ba'i don du gaN+DI brdung ba ni byi bo ste rgyud nyi tshe brdung zhing mjug tu tog mi brdung de// lugs kha cig las (4) ni shi ba'i don du gaN+DI brdung ba la ni rgyud gcig dang tog pa cig go zhi'o//spong ba pa bsdu ba'i don du 'khar gsal gyis gaN+DI'i bya ba bya'o// lugs kha cig las ni spong ba pa'i don du gaN+DI chung ngu brdung ngo zhe'o//ser ba la sogs pa’i gnod pa byung ba’i tshe gaN+DI (5) brdung ba la ni ji tsam gyis chog pa’i bar du brdung bar bya'o/Dge 'dun grub pa: 317b2-5.

93 dge 'dun rnams zan gyi phyir 'du ba'i don du ni gaN+DI dang gaN+DI chung ngu gnyis ka brdung ngo/ Dge 'dun grub pa: 317b5.

94 Although this particular mode of the gaṇdì treatment is mentioned in several sources I did not manage to find any explanation of it. The orthography of this expression in the Tibetan translations of the Gandīsūtra varies. The sDde gde as well as the sNar thang and Co ne redactions read shad $r t s a$, while in the sTog palace version it is written as shing rtsa, and in the lHa sa redaction - shangs tsha. DGS: 303a2; NGS: 469b4; CGS: 359b5; HGS: 561b3; TGS: 286a6. I managed to find the only comment on this action in the monograph by Pozdneev. He describes the procedure of the gandi striking that he observed in one of the Mongolian monasteries and says that before making three successions containing 35 strokes and three separate, louder strokes of the gandi the monk performed three shantsza meaning that he passed the striker over the beam as if caressing it. Pozdneev 1887: 347.

95 gaN+DI bzhag pa’i gnas ni/sgo khang gi steng sogs (5) mtho sar bzhag/brdung ba po ni dge bsnyen yan chad sdom ldan gyis brdung/brdung ba’i tshul ni// bang steng la sogs pa mtho sar phyin nas/dang por dkon mchog la phyag byas shang tsha lan gsum byas nas rgyud gsum dang tog sgra chen po gsum bya ba'am/yang na rgyud (6) gsum dang tog gnyis bya/rgyud re re la sum cu rtsa nga nga ste/brgya rtsa brgyad kyi tshul du bya la de yang zla ba nya ba ltar bya'o/Dge 'dun grub pa: 118b4-6. 
In his manual, Grags pa rgyal mtshan also refers to these questions, but provides an even more detailed explanation regarding the successions and hard strokes:

\begin{abstract}
As to the place in which it is put, it is installed on a platform above the monastery gates, an elevated place in the center of the monastery or similar places. ${ }^{96}$ As to the one who strikes a fully-ordained monk, a novice or a lay devotee observing the poșadha. As to the way of striking, after coming up to the ascended place such as the roof of a building hearable for everybody or similar at first he bows to the three jewels. After that he makes shangs tsha three times and in order to gather for food and drink consumption performs three successions and at the end three very loud strokes. In order to call for poșadha or similar communal sittings as well as for listening to the teachings he makes three 'recitational' successions and three very loud strokes or alternatively three successions and two strokes. In every succession there are 35 strokes made by the hammer. Namely, from the first till the hundred and eighth every next stroke is louder than the previous one. Then every next stroke is quieter than the previous one - certain persons instruct so. According to this, in three successions and three hard strokes there is the usual striking series of $108 .{ }^{97}$
\end{abstract}

We can once again see from the sources that there were different traditions of the gaṇi treatment. It must also be noted that the gaṇ̣̂ is said to be used not only before rituals or official gatherings of the monastic community, but also before mundane activities such as having a meal.

\title{
5.2 Ritual treatment
}

The usage of the gandi in connection with the poșadha ritual presents a special case. It is the only ritual that is distinguished by the sources that speak about the gaṇ̣̂ being struck for communal sittings. The gaṇ̣̂i striking was obviously considered an important part of the ritual, because shorter or longer references

96 Compare with the Gaṇdīsūtra: 'og tu 'ang de yi khri (303a1)/bya ba// gtsug lag khang gi sgo stengs sam// yang na dbus ma'i steng du bya. DGS: 302b7-303a1.

97 de 'jog pa'i gnas ni/gtsug lag khang gi sgo khang gi steng ngam/gtsug lag khang dbus ma'i steng la sogs par khri la gzhag go/[...] /brdung pa po ni/dge slong rnam dag gam/dge tshul rnam dag gam/dge bsnyen gso sbyong la gnas pa'o// ji ltar brdung pa'i tshul ni/kun gyis thos pa’i gnas khang steng la sogs pa mtho sar phyin nas/dang por dkon mchog gsum la phyag byas la/shangs tsha lan gsum byas nas dge 'dun bza' btung la bsdu ba'i phyir ni rgyud gsum dang mjug tu tog sgra chen po gsum bya la/gso sbyong la sogs pa'i las dang chos nyan pa la bsdu ba'i phyir ni bzlas pa'i rgyud (3) gsum dang/tog sgra chen po gsum bya ba'am yang na rgyud gsum dang tog gnyis bya'o// rgyud re re la yang gaN g.yog gis sum cu rtsa lnga re brdeg cing/de yang dang po nas bco brgyad kyi bar du rang rang gi snga ma las phyi ma sgra che bar brdung zhing/de nas rang rang gi snga ma las phyi ma sgra chung bar brdung ngo zhes kha cig bzhed do//de ltar na rgyud gsum dang tog gsum yod pa mams la spyir brdeg thebs brgya rtsa brgyad do/Grags pa rgyal mtshan: 2-3. 
to the beam can be found only in the sources that are entirely devoted to the poșadha such as, for example, the Poșadhavastu, the Bslab pa yongs su sbyong ba'i gzhi gsum gyi cho ga la sogs pa so sor thar pa'i blang dor gyi gnas rnams mdor bsdus pa by 'Dul ba 'dzin pa grags pa rgyal mtshan or the Bslab pa yongs su sbyong ba'i cho ga sdom brtson dgyes byed by Ching su tsug thu no mon han blo bzang nor bu shes rab. For the poșadha ceremony, the gandi striking is an important but ultimately supportive element that signifies the beginning of the main act. Yet, there is one ritual performance in which the beam plays a major role, i.e., the rite of the ganḍ̂̀'s consecration (Tib. rab gnas).

Consecrations are special procedures that constitute an important part of the ritual routine of Buddhist monasteries. As Bentor states: "[n]ot only are consecrations one of the rituals most frequently performed by reincarnated lamas and abbots, they are also the means by which religious objects are made sacred or holy." "98 The consecration of the gaṇdī is described by the Gandịisūtra in only three syntagmas:

The body of a thoroughly taught dharma is virtuous in its being not generated, nondestructable, and unborn from the origin. ${ }^{99}$

This short instruction pertaining to the consecration ritual has drawn special attention from scholars, as it is provided by the sütra genre-affiliated text. This is rather untypical and appears to be a unique case. Bentor specifically refers to this passage when discussing the problem of the existence of the so-called "sūtra-style consecration", as opposed to the consecration procedures found in abundance in the Tantras. ${ }^{100}$

The manual by Grags pa rgyal mtshan appears to mention the same procedure as the Gandisisütra. It is, however, presented by the treatise in a slightly different way:

The consecration ceremony is to be conducted by displaying devotion saying: "The body of the dharma is devoid of arising, ceasing and residing, unborn from the origin and virtuous." 101

Both fragments regard the dharmakāya - characterizing it in the first case as non-created and non-destructible, as well as virtuous by being primordially non-

98 Bentor 1996a: 190.

99 shin tu bstan pa’i chos kyi sku// skyed pa ma yin ’jig byed min// gdod nas ma skyes par dge ba/DGS: 303a1.

100 Bentor 1992: 2-3.

101 chos kyi sku skye 'gag gnas gsum gyis stongs pa gdod nas ma skyes shing dge ba'o//zhes mos pas rab gnas byas pa'o/Grags pa rgyal mtshan: 2. 
arising, and in the second as devoid of the three processes of arising, ceasing and remaining, primordially non-arising and virtuous. The very procedure of the consecration is not entirely clear from these passages. Commenting on the Gandịsūtra citation, Bentor maintains that the consecration "consists in the recitation of three lines of verse". ${ }^{102}$ The version by Grags pa rgyal mtshan can also be understood in this way.

The Kriyāsamgrahanāma offers its own, much more elaborate variant of the gandi consecration. The procedure described by the text proves to be a regular consecration ritual typical of the Tantra literature. It includes inviting the Vajrasattva deity by visualizing it in the form of the samayasattva from its seed syllable, empowering it with the water of the ritual vase by reciting a particular mantra and offering the five dairy products, five nectars and others, worshiping with flowers and so on. ${ }^{103}$

The performance of the consecration ritual of the gandi beam indicates that the instrument has been classified among sacred objects as opposed to it being an ordinary utilitarian tool. Already at the time when the Gandīsūtra was created, that is, likely the first centuries CE, the gandi had the status of a highly venerated religious artefact which was deeply embedded in Buddhist philosophical narratives. It is these narratives that had imbued an instrument like the gaṇ̣̂ with

102 Bentor 1992: 3

103 For details of the standard consecration rituals, see Bentor 1996a: 97-117; Bentor 1996b: 290-299. The performance of the ganḍ̄ consecration is described by the Kriyāsamgrahanāma in the following way:

de (347a) nas slob dpon rdo rje sems dpa'i bdag nyid kyis skad gcig gis zla ba la gnas pa’i $d+h I H$ yig las bskyed pa'i gaN+DI’i mam par bsgoms la rang gi snying ga'i sa bon gyi 'od zer gyis shes kyi gaN+DI gdan drangs la dam tshig sems dpa’i nang du bsgoms nas rang gi sa bon gyis lhag par gnas pa'i bum pa'i chus mngon par dbang bskur la/ oM $d+h I H$ shru ti smri ti ma ti bi dza pra dznyA pra dznyA blo $N+h A$ ra d + hA ra Ni swA hA/ /'dis lan brgya rtsa brgyad bzlas par bya'o//de nas ba'i mam lnga dang bdud rtsi lnga dang dri lnga la sogs pas dbang bskur nas slar yang bkra shis kyi tshigs su bcad pa sngon du 'gro bas bum pa'i chus dbang bskur nas me tog la sogs pas yang dag par mchod nas oM ba dzra bhA Sha raM swA hA zhes pa'i sngags kyis kyang lan bdun lhag par gnas par bya'o/ /de nas paM yig gis bon las skyes pa'i the'ur rnam par bsgoms la/ de nas ye shes sems dpa' rang gi snying ga'i sa bon gyi 'od zer gyis gdan drangs la dam tshig sems dpa'i nang du bsgom par bya'o//rang gi sngags kyis lhag par gnas pa'i bum pa'i chus dbang bskur la me tog la sogs pas yang dag par mchod nas/ oM ba dzra tI? d+haM swA hA/ 'dis lan brgya rtsa brgyad yongs su bzlas par bya'o//de nas lcags kyi mes bsrung ba byas nas mchod yon la sogs pa phul la me tog la sogs pas yang dag par mchod nas lha khang gi nang gi dbang ldan gyi zur du rin po che'i chu skyes kyi steng du bzhugs par bya'o/ /ye d+ha rmA la sogs pa'i tshigs su bcad pas rab tu gnas par bya'o//oM d + hIH $h+r I H$ shru ti smr-I ti ma ti bi dza ye swA hA/'dis lan brgya rtsa brgyad yongs su bzlas par bya'o KrS: 346b-347a. 
so-called "attached" value, in addition to the inherent value that is "intrinsic in the fabric of an object itself" and "established by the rarity of the materials used", ${ }^{104}$ or the complexity of its production process. The attached value does not depend directly on the physical properties of an object and due to its higher variability, is more difficult to estimate precisely. In other words, such symbolic religious objects mean "different things at different times, and can best be understood in the context of the historical process of their development". ${ }^{105}$ In the case of the gaṇịi, textual records seem to be the exclusive sources for both the physical features of the beam and its attached value, revealed through people's attitudes toward the object. The different types of evidence that European scholars obtained and which are available to us for the study of the gandì's history date back only to the end of the nineteenth century and later years.

\section{Testimonies of modernity}

Although described in Buddhist literature, the gandī striking ceremony is rarely mentioned in historical or scientific sources. I only managed to discover one account of this ceremony, given in a monograph by the Russian scholar Pozdneev, who depicts the instrument as a faceted quadrangular wooden beam made predominantly of red sandalwood, with a smooth surface and the images of a frog carved onto both ends. Pozdneev states that the length of the beam equals five ells (Rus. lokot') ${ }^{106}$ with its perimeter being three thirds of an arshin. ${ }^{107}$ The gandì-striker, according to Pozdneev, looked like a small round stick made of the same red sandalwood as the beam itself, having a smooth surface and images of mouse heads on both ends. Pozdneev further states that the procedure of the gandị striking starts with a monk coming up to the büreein shata (Mong. büriy-e-yin šatu) ${ }^{108}$ and carrying the beam on his left shoulder. The monk makes three bows in northerly direction, takes the beam's striker in his right hand and makes three shantsza, which are followed by three separate

104 Prown 1982: 3.

105 Kieschnick 2003: 85

106 Lokot' was a unit of measurement used in medieval Russia. One lokot' equals approximately $54 \mathrm{~cm}$.

107 Arshin is a unit of measurement that has been commonly used in Russia since the second half of the sixteenth century. It measures around $70 \mathrm{~cm}$.

108 Büriy-e-yin šatu is a wooden raised platform erected on four poles at a height of 1.5 or 2 sazhen', which is approximately three to four metres. A wooden ladder is attached to the platform. The platform is used to call the monks of a monastery for gatherings and services. Pozdneev 1887: 30. 
strong strokes and three successions of 35 strokes each. Pozdneev goes on to say that the summoning of the monks for the poșadha ritual was carried out with the help of this special device in the Mongolian monasteries in the second half of the nineteenth century. ${ }^{109}$ In his monograph, Pozdneev provides a detailed description of the economic, household, ritualistic and educational routine of the Mongolian Buddhist monasteries of this period. However, the gandi beam is mentioned only once in connection with the poșadha. It is therefore reasonable to assume that the ceremony of the gaṇi striking was performed exclusively as an initial part of the poșadha ritual. ${ }^{110}$

The appearance of the gandi was reported in yet another academic work dating to the beginning of the twentieth century. In the introduction to his monograph devoted to the Sanskrit text of the Gandịstotragāthā and preserved in a Chinese transcription, Staël-Holstein presents a drawing by S.M. Dudin that shows the gandī of the Saint-Petersburg Buddhist temple and its striker, and which provides measurements for both instruments. According to Staël-Holstein, the gandi in in question was made of palisander, $173 \mathrm{~cm}$ in length and $5.5 \mathrm{~cm}$ thick. Regarding its width, in the widest area it measured $10.5 \mathrm{~cm}$. The length of the gandî̀-striker equalled $43.7 \mathrm{~cm}$ with its circumference being $5.8 \mathrm{~cm}$ at the thickest point. The picture shows that neither the gaṇ̣i nor the striker had any decorations at their ends (see Figure 3). ${ }^{111}$

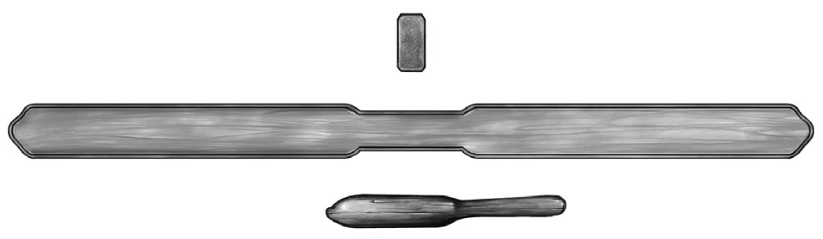

Figure 3: Illustration of the ganḍī and the ganḍ̂i-striker used in the Buddhist temple of SaintPetersburg in the beginning of the twentieth century. ${ }^{112}$

In her article on the gandi Helffer provides us with a photograph of a chanting master holding the instrument. The photograph was taken in Darjeeling, West Bengal, India in August 1979. ${ }^{113}$ The gandi presented in the image has no decorations. Its surface is smooth and of the same width along its entire length.

109 Pozdneev 1887: 346-347.

110 Pozdneev 1887: 346-347.

111 Staël-Holstein 1913: XXI.

112 The illustration was made by P. Sobkowiak from the drawing by S.M. Dudin.

113 Helffer 1983: 119. 
It looks very similar to the instrument currently used in the Gandantegchenlin monastery in Ulan Bator.

I took a photograph of the gandī in June 2011 while conducting field research on the poșadha tradition in contemporary Mongolia. The ritual of poșadha is a strictly monastic, closed ceremony. No lay person is allowed to be present at the ceremony or to take part in it. For this reason it is impossible for a researcher to have first-hand experience of the performance and to give an eyewitness account of it. One is, however, allowed to observe how the only public part of the poșadha is conducted. This particular part consists of the gandịi beam-striking rite.

It is not uncommon that a ritualized action is preceded and immediately followed by specific acts. Although those acts are not essential for the very process of ritualization, they serve to mark the boundaries between non-ritualized and ritualized activity. ${ }^{114}$

In the case of the poșadha as it is performed in contemporary Mongolia, the most prominent boundary-marking act of the ritual is the gandi beam-striking ceremony.

The ceremony is performed in four steps: a novice monk carries the beam called in Mongolian gandi or gandi mod (ModMong.) and a fully ordained monk carries a beam-striker, they ascend to an elevated place or raised platform (see Figure 4); the fully ordained monk who is to perform the striking makes

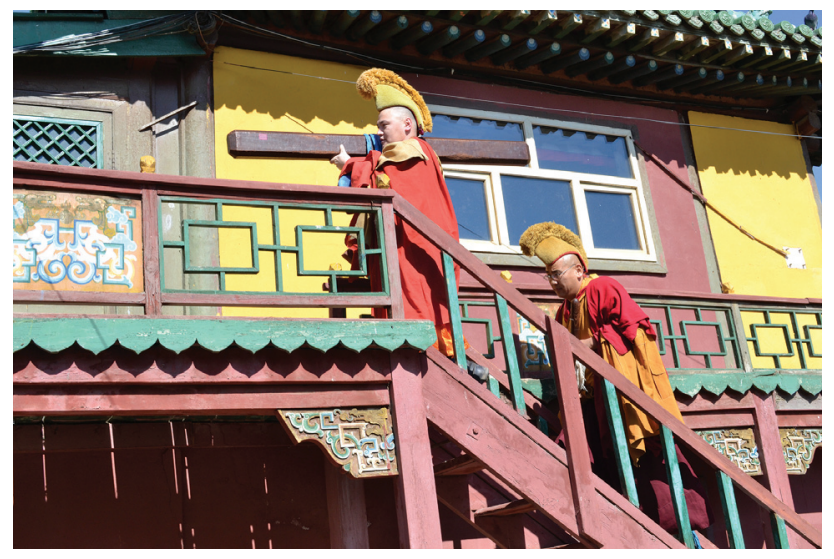

Figure 4: Gaṇ̣̂i-striking ceremony performed on 30 June 2011 in the Gandantegchenlin monastery in Ulan Bator. The monks ascend to an elevated platform.

114 Humphrey/Laidlaw 1994: 77. 
three bows (see Figure 5); the fully ordained monk takes the beam and the beam-striker and strikes the beam in a special manner 108 times (see Figure 6); the monks descend from the platform and proceed directly to the temple in which the posadha ceremony is to be conducted.

At least in some monasteries, the tradition of the gandī-beam striking is maintained. The monks whom I interviewed in the course of field research conducted in summer 2011 in the monasteries of Gandantegchenlin, Dashchoilin, Betüv, Amarbayasgalant of Mongolia and the Ivolginskii dacan in Buryatia

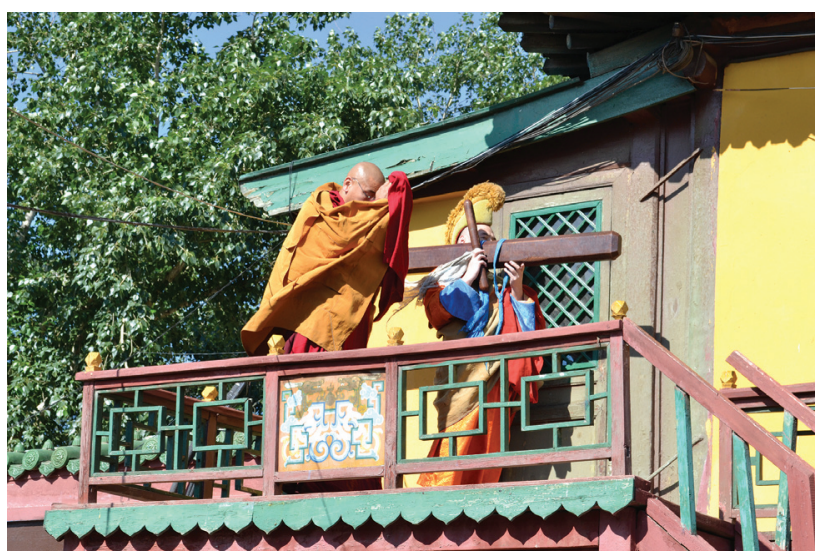

Figure 5: Gandī-striking ceremony performed on 30 June 2011 in the Gandantegchenlin monastery in Ulan Bator. A fully ordained monk is making three bows praising the Buddha.

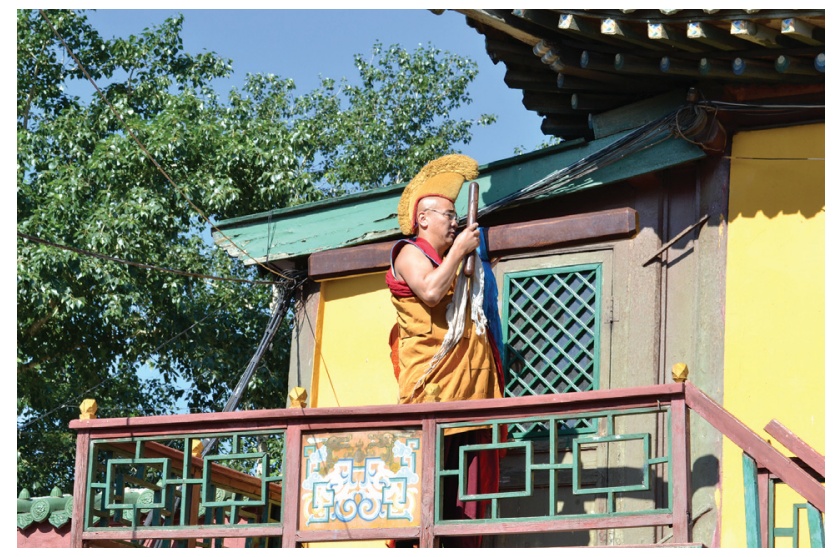

Figure 6: Gaṇdī-striking ceremony performed on 30 June 2011 in the Gandantegchenlin monastery in Ulan Bator. A fully ordained monk is performing the gậ̣̄i beam striking. 
(Russian Federation) confirmed the usage of the gaṇ̣i in their monasteries' activities. Their reports which specify those activities, however, differ. The monks from the Amarbayasgalant and Gandantegchenlin monasteries claimed that in their communities the gandi is struck solely before the poșadha, and serves to mark the beginning of this ritual alone. Meanwhile my respondents in the Dashchoilin and Betüv monasteries stated that the ganḍi is used on various occasions, and its application is not exclusively associated with the poșadha ritual.

Speaking about manuals which describe details of the gandī application and which are currently used in the Mongolian Buddhist monasteries, only one of my respondents mentioned that kind of texts. He was a dge slong of the Gandantegchenlin monastery of Ulan Bator called Gantulga. In the course of our conversation he gave an extended description of the manner in which the gandi should be manipulated. Responding to my question on the source of these data he only referred to the existence of a number of Tibetan texts providing the information on the gandī handling but did not specify them by titles. Inquiring into the corpus of texts on which modern Mongolian Buddhist monks rely when studying the rules and mastering the methods of the gandi ${ }^{\prime}$ s physical treatment should therefore be considered as a promising direction of further research on the cultural history of the instrument.

As I observed in the course of my fieldwork in the Gandantegchenlin monastery of Ulan Bator, the appearance of the gandi does not correspond with the descriptions found in the sources cited above. Furthermore the beam does not look similar to the image presented by Staël-Holstein and is not exactly like the instrument mentioned by Pozdneev. It is a smooth beam without any decorations, painted or carved and has the same width along its entire length. It is a prism in cross-section. The gandi-striker is round in cross-section and has the same circumference along its entire length. Its ends are not cut perpendicularly to the axis but made round in the form of hemispheres. As the beam itself, the striker is not adorned in any way.

The usage of the beam, or, at least, the way in which it is used before the posadha, is in the main symbolical and ritualistic. The purpose of the performance can be determined as purely spiritual. This coincides well with what is written about the instrument in the original sources. My respondent in the Gandantegchenlin monastery informed me that the beam is a material representation of the Prajñyāpa aramitā. For this reason, the instrument came to possess certain intangible, metaphysical qualities. As such, the sound of the gandi brings good fortune to all living creatures and helps to circumvent bad destinies.

The fact that the striking of the beam is considered to be an obligatory part of the poșadha might be related to the special importance attributed to the latter. 
The proper performance of the poșadha is of great significance for the monastic community to prove and maintain its legitimacy and authenticity. Although the gandì-striking has nothing to do with the content of the ritual it is obviously believed to be an indispensable element of its structure. It might be that without the gandi-striking preceding it the very ritual of poșadha would be regarded as incomplete, and therefore not valid.

\section{Conclusion}

The modern Mongolian tradition of the gaṇī treatment is first of all based on the attached, symbolical value of the artefact. The transcendent powers attributed to the beam, thanks to its incorporation into the complex system of Buddhist philosophy and mythology, are actively exploited by religious specialists, that is, the Buddhist clergy, and are also readily appreciated by the laity. Used exclusively for the performance of inner, monastic rituals such as the poșadha, the gaṇī facilitated interaction between monkhood and lay followers on the social level, and between humans and divine entities on the transcendent level. To me, these functions of the object were most visible when I observed the final phase of the gandī striking, performed as an introductory part of the poșadha in the Gandantegchenlin. While the monk performed the striking a group of lay devotees gathered below the platform on which he conducted the ceremony. After he finished and went down from the platform, the people rushed to him one by one to get the blessing which he granted by touching their bowed heads with the gandīi-striker (see Figure 7).

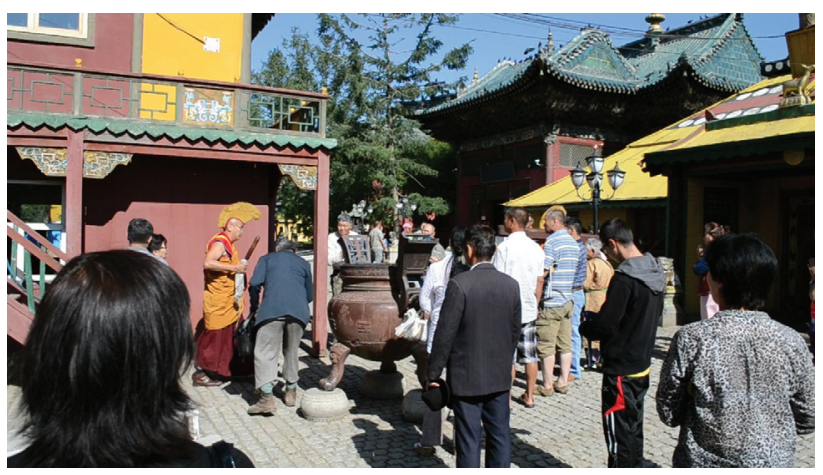

Figure 7: A monk blesses lay people with the ganḍ̂i-striker. Gandantegchenlin monastery, Ulan Bator, June 2011. 
Another important function of the artefact is its role in creating and manifesting communal identity. ${ }^{115}$ By keeping and applying the gandī as required by the Buddhist monastic tradition, as established in theoretical texts and over time and through practice of ritual performances, the Mongolian clergy seeks to demonstrate the genuine character of the monastic community and its spiritual maturity. It furthermore attempts to confirm the legitimate status of the community and its members. This seems to be even more so as the gandī-striking ceremony is conducted in direct relation with the poșadha, which is one of the most important rituals in the monthly ritual schedule of a monastery and acts to confirm and strengthen the unity of this community. The experience of the gandi treatment shared by monks and lay people naturally helps to create a sense of belonging in a community that adheres to the same religious ideals and preserves its corporate unity and identity by maintaining traditions.

Yet what can we say about the object's "social work" after having analyzed various examples of the intellectual perception and physical treatment of the gandi beam? Has the nature of this work changed over time? It is difficult to say how characteristic the application of the gandī was to the Indian Buddhist monastic communities or, in other words, whether possession and usage of the gaṇdi was one of the characteristic features that defined a community as Buddhist. We only know that at the time when the Buddhist monasteries in India were growing into well-developed socio-economical organizations, the gandī was a regular monastic tool of rather utilitarian nature. However, the information is not enough to establish what the attitude of the laity to the instrument was.

Taking the special case of the modern Mongolian Buddhist monasteries we can say that the gandi has evolved into a highly specific religious object, which manages to signify the cultural identity of the people who handle it. It has also maintained its initial ability to order time and space. The number of occasions that it marks temporally and spatially has decreased and therefore its significance in fulfilling these tasks has grown.

The cultural history of the gandi constitutes a good example of how a tangible object has gradually become a part of an intangible heritage of a religious transnational culture by having become deeply embedded in the various narratives that represent the divergent traditions of this culture. Taking into consideration the large amount of original texts which refer to the instrument and its treatment, as well as the inconsistency of information provided in these sources, further research seems promising. In this regard, a task might be to thoroughly analyze the sources, which obviously follow different

115 Morgan 2005: 59. 
traditions of the gaṇ̂̄ perception and handling, and to trace these traditions up to the present day by researching contemporary Buddhist monastic communities.

\section{Abbreviations}

\begin{tabular}{|c|c|}
\hline BHSD & Buddhist Hybrid Sanskrit Dictionary \\
\hline CGS & GaN Dl’i mdo, Co ne bka' 'gyur \\
\hline Cho ga & $\begin{array}{l}\text { Bslab pa yogs su sbyong ba'i cho ga sdom brtson dgyes byed ces bya } \\
\text { ba bzhugs so }\end{array}$ \\
\hline DGS & GaN Dl’i mdo, sDe dge bka' 'gyur \\
\hline Dung dkar & Dung dkar tshig mdzod chen po \\
\hline Grags pa rgyal mtshan & $\begin{array}{l}\text { Bslab pa yongs su sbyong ba'i gzhi gsum gyi cho ga la sogs pa so sor } \\
\text { thar pa'i blang dor gyi gnas rnams mdor bsdus pa by Rje 'dul ba 'dzin } \\
\text { pa chen po grags pa rgyal mtshan }\end{array}$ \\
\hline HGS & GaN + Dl'i mdo, IHa sa bka' 'gyur \\
\hline $\mathrm{KrS}$ & Bya ba bsdus pa zhes bya ba by Rigs kyis byin \\
\hline NGS & GaN Dl'i mdo, sNar thang bka' 'gyur \\
\hline PTSD & The Pali Text Society's Pali-English Dictionary \\
\hline PV & Gso sbyong gi gzhi \\
\hline TGS & GaN Di’i mdo, the Stog Palace Manuscript of the Tibetan Kanjur \\
\hline Tshig mdzod & Bod rgya tshig mdzod chen mo \\
\hline
\end{tabular}

\section{Bibliography}

Beer, Robert (2003): The Handbook of Tibetan Buddhist Symbols. Chicago, London: Serindia.

Bentor, Yael (1992): "Sūtra-style consecration in Tibet and Its Importance for Understanding the Historical Development of the Indo-Tibetan Consecration Ritual for Stūpas and images”. In: Tibetan Studies: Proceedings of the $5^{\text {th }}$ Seminar of the International Association for Tibetan Studies, Narita, 1989. Edited by Ihara Shōren et al. Narita: Naritasan Shinshoji, 1-12.

Bentor, Yael (1996a): Consecration of Images and Stūpas in Indo-Tibetan Tantric Buddhism. Leiden et al.: E.J. Brill.

Bentor, Yael (1996b): “Literature on Consecration (Rab gnas)”. In: Tibetan Literature: Studies in Genre. Edited by José Ignacio Cabezón and Roger Jackson. Ithaca, NY: Snow Lion, 290-311.

Berger, Patricia (1995): “After Xanadu”. In: Mongolia: the Legacy of Chinggis Khan. Edited by Patricia Berger and Therese Tse Bartholomew. New York: Thames and Hudson, 50-75.

Bod rgya tshig mdzod chen mo (1996): Beijing: Minzu Chubanshe.

Böhtlingk, Otto/Roth, Rudolph. (1858): Sanskrit-Wörterbuch. Zweiter Theil. St. Petersburg: Buchdruckerei der kaiserlichen Akademie der Wissenschaften.

Burke, Peter (2008): Eyewitnessing. The Uses of Images as Historical Evidence. Ithaca, NY: Cornell University Press. 
Buswell, Robert E./Lopez, Donald S. (2014): The Princeton Dictionary of Buddhism. Princeton, Oxford: Princeton University Press.

Ching su tsug thu no mon han blo bzang nor bu shes rab (1996): "Bslab pa yogs su sbyong ba'i cho ga sdom brtson dgyes byed ces bya ba bzhugs so". In: Gsung 'bum. Vol. 1. Pe cin par khang, 181-234.

Das, Sarat Chandra (1902): A Tibetan-English Dictionary: with Sanskrit Synonyms. Calcutta: Bengal Secretariat Press.

dGe 'dun grub pa. Legs par gsungs pa'i dam pa'i cho 'dul ba mtha' dag gi snying po'i don legs par bshad pa rin po che'i phreng ba zhes bya ba'i smad chaa shog grangs. Xylograph. 'Bras spungs dga' Idan pho brang.

Dung dkar blo bzang 'phrin las (2002): Dung dkar tshig mdzod chen po. Beijing: Krung go'i bod rig pa dpe skrun khang.

Edgerton, Franklin (1972): Buddhist Hybrid Sanskrit Grammar and Dictionary. Vol. 2. Delhi: Motilal Banarsidass.

GaN Dl'i mdo. Co ne bka' 'gyur, mdo sde, vol. 51 (sha), 357b-360b. 1729-1733. Co ne par khang.

GaN Dl'i mdo. sDe dge bka' 'gyur, mdo sde, vol. 71 (sha), 301b-303b. 1976-1979. Delhi.

GaN Dl'i mdo. sNar thang bka' 'gyur, mdo sde, vol. 71 (ra), 468a-471b. 1730-1732. Snar thang par khang.

GaN Di'i mdo (1975-1980): The Stog Palace Manuscript of the Tibetan Kanjur, mDo sde, vol. 67, 283b-287a. Leh, Ladakh: Smanrtsis Shesrig Dpemzod.

GaN + Dl'i mdo. IHa sa bka' 'gyur, mdo sde, vol. 71 (ra), 557a-561b. 1934. Lhasa: Zhol bka' 'gyur par khang.

Garab Dorje (1996): The Golden Letters: the Three Statements of Garab Dorje, the First Teacher of Dzogchen, together with a Commentary by Dza Patrul Rinpoche Entitled "The Special Teaching of the Wise and Gloriuos King”. Translated, introduced and commented by John Myrdhin Reynolds. Ithaca, NY: Snow Lion Publications.

Gethin, Rupert (1998): The Foundations of Buddhism. Oxford: Oxford University Press.

Grupper, Samuel M. (1979): The Manchu Imperial Cult of the Early Ch'ing Dynasty: Texts and Studies on the Tantric Santuary of Mahakala at Mukden. PhD dissertation, Indiana University.

Grupper, Samuel M. (1984): "Manchu Patronage and Tibetan Buddhism During the First Half of the Ch'ing Dynasty. A Review Article". Journal of the Tibetan Society 4: 47-75.

Grünwedel, Albert (1900): Mythologie des Buddhismus in Tibet und der Mongolei. Leipzig: F.A. Brockhaus.

Gso sbyong gi gzhi. sDe dge bka' 'gyur, 'dul ba,vol. 1 (ka), 131a-221b. Sde dhe par khang chen mo.

Harré, Rom (2002): “Material Objects in Social Worlds". Theory, Culture and Society 19.5/6: 23-33.

Helffer, Mireille (1983): “Le Gandi: un Simandre Tibétain d’Origine Indienne”. Yearbook for Traditional Music 15 (East Asian Music): 112-125.

Hirakawa, Akira (1990): A History of Indian Buddhism: From Śākyamuni to Early Mahāyāna. Hawaii: University of Hawaii Press.

Humphrey, Caroline/Laidlaw, James (1994): The Archetypal Actions of Ritual: A Theory of Ritual Illustrated by the Jain Rite of Worship. Oxford: Clarendon Press.

Huntington, John C./Bangdel, Dina (2003): The Circle of Bliss: Buddhist Meditational Art. Columbus, $\mathrm{OH}$ : Columbus Museum of Art. 
Hu-von Hinüber, Haiyan (1991): “Das Anschlagen der Gaṇ̣̂i in buddhistischen Klöstern. Über einige einschlägige Vinaya-Termini”. In: Papers in Honour of Prof. Dr. Ji Xianlin on the Occasion of His 80th Birthday. Edited by Li Zheng and Jiang Zhongxin. Peking: Peking University Press.

Hu-von Hinüber, Haiyan (1994): Das Poșadhavastu. Vorschriften für die buddhistische Beichtfeier im Vinaya der Mūlasarvāstivādins: aufgrund des Sanskrit-Textes der GilgitHandschrift und der tibetischen Version sowie unter Berücksichtigung der SanskritFragmente des Poșadhavastu aus zentralasiatischen Handschriftenfunden herausgegeben, mit den Parallelversionen verglichen, übersetzt und kommentiert. Reinbek: Inge Wezler.

Kas’yanenko, Zoya (1993): Katalog Peterburgskogo Rukopisnogo “Gandzhura”. Compilation, introduction, transliteration and indexes by Z. Kas'yanenko. Moscow: Vostochnaya Literatura.

Kieschnick, John (2003): The Impact of Buddhism on Chinese Material Culture. Princeton, NJ: Princeton University Press.

Ligeti, Louis (1942): Catalogue du Kanjur Mongol Imprimé. Budapest: Société Kőrösi Csoma. Lokesh, Chandra (1992-1994): Tibetan-Sanskrit Dictionary. Vol. 7. New Delhi: International Academy of Indian Culture.

Monier-Williams, Monier (1974): Sanskrit-English Dictionary: Etymologically and Philologically Arranged with Special Reference to Cognate Indo-European Languages. Oxford: Clarendon Press.

Morgan, David (2005): The Sacred Gaze. Religious Visual Culture in Theory and Practice. Berkeley et al.: University of California Press.

Mylius, Klaus (1992): Wörterbuch Sanskrit-Deutsch. Leipzig et al.: Langenscheidt Verlag Enzyklopädie.

Nientiedt, Susa (2007): Mahakala, der große Schwarze, Shri Devi und Ekajata. Ursprung, Ausstrahlungen und Bedeutung. Bochum: Verrückter Yogi Verlag.

Pozdneev, Aleksey (1887): Ocherki Byta Buddiyskikh Monastyrey i Buddiyskogo Dukhovenstva v Mongolii v Svyazi s Otnosheniyami Sego Poslednego k Narodu. S.-Petersburg: Tipografiya Imperatorskoy Akademii Nauk.

Prown, Jules David (1982): “Mind in Matter: An Introduction to Material Culture Theory and Method”. Winterthur Portfolio 17.1: 1-19.

Rhie, Marylin (2004): “Mahakala”. In: Demonic Divine: Himalayan Art and Beyond. Edited by Rob Linrothe and Jeff Watt. Chicago: Serindia Publications.

Rhys, Davids et al. (eds.) (1921-1925): The Pali Text Society's Pali-English Dictionary. Part III. London: The Pali Text Society.

Rigs kyis byin (1982-1985): “Bya ba bsdus pa zhes bya ba”. In: sDe dge bstan 'gyur. rGyud, vol. $62(\mathrm{Ku})$. Facsimile, India, 227-362.

Rje 'dul ba 'dzin pa chen po grags pa rgyal mtshan (2001): "Bslab pa yongs su sbyong ba'i gzhi gsum gyi cho ga la sogs pa so sor thar pa'i blang dor gyi gnas rnams mdor bsdus pa”. In: Bslab pa yongs su sbyong ba'i gzhi gsum sogs kyi skor bzhugs so. Lan kru'u: Kan su'u mi rigs dpe skrun khang, 1-88.

Rospatt, Alexander von (2010): "Remarks on the Consecration Ceremony in Kuladatta's Kriyāsamgrahapañjika and Its Development in Newar Buddhism". In: Hindu and Buddhist Initiations in India and Nepal. Edited by Astrid Zotter and Christof Zotter. Wiesbaden: Harrassowitz Verlag, 197-260.

Sakaki, Ryōzburō (1925): Mahāvyutpatti. Kyoto: Kyoto Imperial University. 
Schopen, Gregory (1992): "On Avoiding Ghosts and Social Censure: Monastic Funerals in the Mūlasarvāstivāda-Vinaya”. Journal of Indian Philosophy 20.1: 1-39.

Schopen, Gregory (2004): Buddhist Monks and Business Matters: Still More Papers on Monastic Buddhism in India. Honolulu, HI: University of Hawai’i Press.

Schumann, Hans Wolfgang (1993): Buddhistische Bilderwelt: ein ikonographisches Handbuch des Mahāyāna- und Tantrayāna-Buddhismus. München: Eugen Diederichs.

Staël-Holstein, Alexander von (1913): Kien-ch'ui-fan-tsan (Ganḍīstotragāthā), Sokhranivshiysya v Kitayskoy Transkriptsii Sanskritskiy Gimn Açvaghoș'i, Ts'ih-fuh-tsan-pai-k'ie-t'o (Saptajinastava) i Fuh-shwoh-wăn-shu-shi-li-yih-poh-pah-ming-fan-tsan (Āryamañjuçrīnāmāșțaçtaka). Saint-Petersburg.

Tanemura, Ryugen (1992): “The Four Nikāyas Mentioned in the Gaṇ̣īlakșaṇa Chapter of the Kriyāsaṃgraha”. Journal of Indian and Buddhist Studies 41.2: 1123-1121.

Tenzin Gyatso (2000): The Opening of the Wisdom-eye and the History of the Advancement of Buddhadharma in Tibet. Illinois: Theosophical Publishing House.

Tucci, Giuseppe (1989): Gyantse and lits Monasteries. Part I. Edited by Lokesh Chandra. New Delhi: Aditya Prakashan.

Ui, Hakaju et al. (eds.) (1934): A Complete Catalogue of the Tibetan Buddhist Canons (Bkahhgyur and Bstan-hgyur). Sendai, Japan: Tôhoku Imperial University.

Waddell, Laurence Austin (1895): The Buddhism of Tibet or Lamaism. London: W.H. Allen \& Co., Limited.

Willson, Martin/Brauen, Martin (eds.) (2000): Deities of Tibetan Buddhism: the Zürich Paintings of the Icons Worthwhile to see (Bris sku mthon ba don Idan). Translated by Martin Willson; introduced by Martin Brauen; line drawings by Robert Beer; photographs by Peter Nebel. Boston, MA: Wisdom Publications.

Woodward, Ian (2007): Understanding Material Culture. Los Angeles et al.: Sage Publications. 